\title{
Review \\ Synthesis and Potential Applications of Lipid Nanoparticles in Medicine
}

\author{
Ewelina Musielak, Agnieszka Feliczak-Guzik (1) and Izabela Nowak *(D)
}

Citation: Musielak, E.;

Feliczak-Guzik, A.; Nowak, I.

Synthesis and Potential Applications of Lipid Nanoparticles in Medicine. Materials 2022, 15, 682. https:// doi.org/10.3390/ma15020682

Academic Editor: Leonid Gurevich

Received: 10 December 2021

Accepted: 11 January 2022

Published: 17 January 2022

Publisher's Note: MDPI stays neutral with regard to jurisdictional claims in published maps and institutional affiliations.

Copyright: (C) 2022 by the authors. Licensee MDPI, Basel, Switzerland. This article is an open access article distributed under the terms and conditions of the Creative Commons Attribution (CC BY) license (https:// creativecommons.org/licenses/by/ $4.0 /)$.
Faculty of Chemistry, Adam Mickiewicz University in Poznań, Uniwersytetu Poznańskiego 8, 61-614 Poznań, Poland; ewelina.musielak@amu.edu.pl (E.M.); agaguzik@amu.edu.pl (A.F.-G.)

* Correspondence: nowakiza@amu.edu.pl; Tel.: +48-618-291-580

\begin{abstract}
Currently, carriers of active ingredients in the form of particles of a size measured in nanometers are the focus of interest of research centers worldwide. So far, submicrometer emulsions, liposomes, as well as microspheres, and nanospheres made of biodegradable polymers have been used in medicine. Recent studies show particular interest in nanoparticles based on lipids, and at the present time, are even referred to as the "era of lipid carriers". With the passage of time, lipid nanoparticles of the so-called first and second generation, SLN (Solid Lipid Nanoparticles) and nanostructured lipid carriers and NLC (Nanostructured Lipid Carriers), respectively, turned out to be an alternative for all imperfections of earlier carriers. These carriers are characterized by a number of beneficial functional properties, including, among others, structure based on lipids well tolerated by the human body, high stability, and ability to carry hydro- and lipophilic compounds. Additionally, these carriers can enhance the distribution of the drug in the target organ and alter the pharmacokinetic properties of the drug carriers to enhance the medical effect and minimize adverse side effects. This work is focused on the current review of the state-of-the-art related to the synthesis and applications of popular nanoparticles in medicine, with a focus on their use, e.g., in COVID-19 vaccines.
\end{abstract}

Keywords: nanotechnology; nanostructured materials; lipid nanoparticles; biocompatible pharmaceutical carriers

\section{Introduction}

The intensive development of nanotechnology and continuous work on the miniaturization of technological objects has resulted in the possibility of obtaining structures with sizes not exceeding $100 \mathrm{~nm}$. Reducing the particle size of materials to the nanometer scale makes it possible to increase their total surface area by several orders of magnitude. Such objects are called nanoparticles, and methods for their production are the subject of nanotechnology. The origin of the term "nano" is derived from the Greek word "nanos", which means "dwarf" [1]. Nanoparticles are very attractive research topics due to their potential applications in biotechnology, pharmaceuticals, and optics, but most importantly in medicine [2]. The number of reports and articles on nanoparticles is significant and is expected to increase in the next few years.

Nanoparticles are defined as particles with at least one spatial dimension, not exceeding $100 \mathrm{~nm}$ [3]. According to their origin, they can be divided into two types. Natural nanoparticles are commonly found in the natural environment, mostly in volcanic smoke. Natural nanoparticles are produced by the erosion of geological materials and the degradation of biological materials, mainly vegetable residues, and can be produced by combustion processes. The second type is engineered nanoparticles (designed) with a small size that show a tendency towards fast aggregation. Engineered nanoparticles include fullerenes, carbon nanotubes, quantum dots, and nanofibers [4].

The use of nanoscale materials provides great freedom to modify basic parameters such as immunogenicity, diffusivity, solubility, half-life in the bloodstream, and release rate 
of the active substance. Over the past two decades, several nanoparticle-based therapeutic agents have been developed for the treatment of diabetes, asthma, allergies, pain, infections, and others [5].

The role of nanomedicine is to provide more efficient tools to prevent and treat various diseases through the interaction of nanomaterials with biological molecules. Nanomedicinebased strategies have opened new horizons for biomedical engineers and clinicians in the prevention, diagnosis, and treatment of serious diseases. With nanotechnology applied to medicine, significant improvements have been registered in drug delivery systems, protein detection, cancer treatment, medical imaging and diagnostic platforms, implantable materials, and tissue regeneration strategies, among others [6,7]. It is important to mention that various nanosystems are already being used with a positive impact on human health and that even more medical projects are in development.

Among the nanoparticles described above, in recent years, lipid nanoparticles have received the most attention from researchers because drug delivery systems based on them, because of their lipophilicity, show the ability to overcome difficult physiological barriers, such as blood-brain, even without surface modification. Other very important beneficial properties offered by lipid nanoparticles are high skin compatibility, higher penetration through the stratum corneum, high mechanical and chemical versatility, biodegradability, and protection of the active ingredient from degradation processes induced by external factors. The lipid nanoparticles show low toxicity, have good conformity with biological substances, and most of the preparation methods can be easily scaled up. However, additional studies are necessary on the interaction and boundary of active substances with lipids and surfactants/emulsifiers and on the mechanisms of diffusion and cellular uptake to achieve optimal working conditions. Another important hot topic to be elaborated on is the problems related to the encapsulation of hydrophilic compounds. The important concepts to be addressed while encapsulating hydrophilic compounds include the solubility of the molecule, the partitioning of the active substance and lipid, and the mass transport phenomena. The solubility of the bioactive compound or drug must always be analyzed not only in the different phases of the delivery system but also in the surrounding application matrix.

\section{Characteristics of Nanoparticles}

Nanoparticles as drug carriers are gaining popularity, mainly due to their small size and unique properties that make them attractive in many fields of science. Such carriers offer a number of important benefits, including protection of the active ingredient from moisture, physiological $\mathrm{pH}$, and enzyme activity. Of the group of nanocarriers shown in Figure 1, liposomes, niosomes [1], and lipid matrix nanoparticles, including solid lipid nanoparticles (SLN) and nanostructured lipid carriers (NLCs) [2,8,9], have received particular attention.

Currently, the most popular carriers for active ingredients are solid lipid nanoparticles (SLNs, first-generation lipid nanoparticles) and nanostructured lipid carriers (NLCs, secondgeneration lipid nanoparticles) [10]. Second-generation nanoparticles were synthesized to improve the properties of the first-generation particles. The most significant difference between these two types of systems is the incorporation of liquid lipids into the structure of NLC-type materials [11]. 


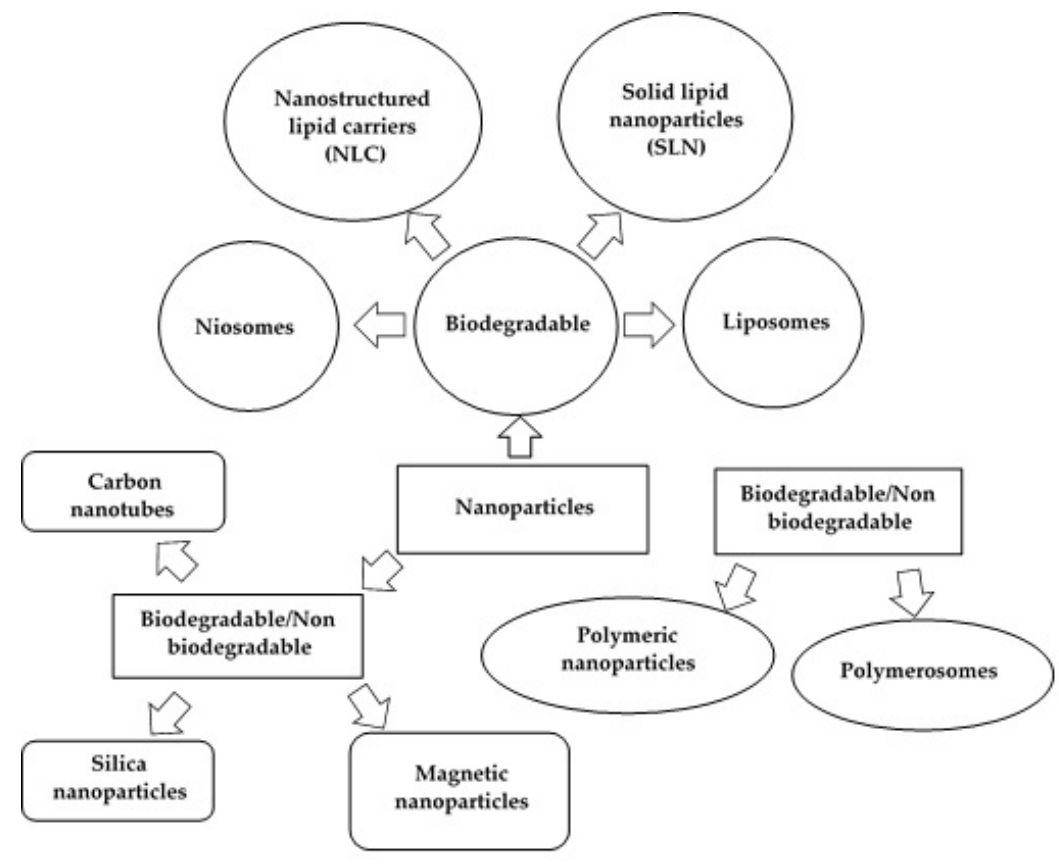

Figure 1. Schematic diagram showing different types of nanoparticles (modified from [1]; original paper under the terms of the Creative Commons CC BY-NC 3.0).

\section{Liposomes}

Liposomes are spherical vesicles, $0.01-1 \mu \mathrm{m}$ in size, composed of 1 or more phospholipid bilayers formed from cholesterol and other natural phospholipids, separated by spaces containing water $[12,13]$. Typically, compounds that form the lipid bilayer are phosphatidylcholine (PC), phosphatidylglycerol (PG), dipalmitoylphosphatidylcholine (DPPC), distearoylphosphatidylcholine (DSPC), cholesterol (CH), stearylamine, dicetyl phosphate, or mixtures thereof $[14,15]$.

The size of the vesicle is an important parameter in estimating the half-life of liposomes in the bloodstream. Both the size of the liposome and the number of bilayers in it have a great influence on drug encapsulation [14]. According to the size, the number of bilayers, and the way liposomes are obtained, they can be divided into [16]:

- multilamellar vesicles MLV;

- unilamellar vesicles UV;

- small unilamellar vesicles SUV;

- large unilamellar vesicles LUV;

- multivesicular vesicle MVV.

The size of a small unilamellar vesicle SUV is in the range of $0.02-0.1 \mu \mathrm{m}(20-100 \mathrm{~nm})$, while the size of LUV vesicles is $>0.1 \mu \mathrm{m}(100 \mathrm{~nm})$ and MLV vesicles $>0.5 \mu \mathrm{m}(500 \mathrm{~nm})$. Multilamellar vesicle structures are $>1 \mu \mathrm{m}(1000 \mathrm{~nm})$ in size. For medical applications of liposomes related to drug delivery, the desired size is in the range of $0.05-0.2 \mu \mathrm{m}$ $(50-200 \mathrm{~nm})$ [16].

Unilamellar liposomes are composed of a single phospholipid bilayer surrounding an aqueous solution, whereas multilamellar liposomes form an onion-shaped structure. Classically, in the case of multilamellar liposomes, several monolayer vesicles of smaller size are formed on the inner side of the second layer, forming a multilamellar structure of concentric lipid globules separated by layers of water [17].

Liposomes occur naturally in living organisms, for example, in blood, but can also be produced for the pharmaceutical and cosmetic industries [13]. They are classified as vesicular delivery systems that can carry hydrophilic or hydrophobic substances. They are small spherical particles, have high EE\% (encapsulation efficiency) of the drug, and contain an inner aqueous core and an outer double lipid layer [18]. 
The properties of liposomes depend on their composition and size, method of production, and quantity of the surface charge. By selecting appropriate components of the bilayer, it is possible to adjust its stiffness, fluidity, and surface charge. For example, the use of phosphatidylcholine from natural sources (eggs or soy) makes the bilayer less rigid and more permeable. In contrast, the use of phospholipids with long acyl chains makes the resulting bilayer rigid and impermeable [14]. Liposomes, due to their unique properties, can be used in medicine. Their clinical applications include cancer treatment and antimicrobial and gene therapies [19-21].

Liposomes exhibit a number of special biological features, including (specific) interactions of liposomes with biological membranes. The main advantages of liposomes are biocompatibility, biodegradability, and non-immunogenicity. They are flexible, non-toxic, and increase of efficacy and therapeutic index of a drug. Liposomes increase drug/molecule stability as a result of encapsulation. The disadvantages of liposomes are low solubility and stability, short half-life, and high production cost. There is a possibility of phospholipid oxidation and hydrolysis-like reaction [14].

\subsection{Methods for Obtaining Liposomes}

There are several basic strategies involved in the synthesis of liposomes for various applications. They include four basic steps:

- separation of the lipids from the organic solvent;

- dispersion of the lipids in an aqueous medium;

- purification of the resulting liposome;

- $\quad$ analysis of the final product.

The most variable step in the process of obtaining liposomes is the dispersion of lipids in an aqueous medium [12]. The most common methods for obtaining liposomes are summarized in Table 1.

Table 1. The most common methods for producing liposomes.

\begin{tabular}{|c|c|c|}
\hline Type of Method & Description of the Method & Ref. \\
\hline Sonication & $\begin{array}{l}\text { MECHANICAL DISPERSION METHOD } \\
\text { Sonication is the best-known and widespread method for the synthesis of } \\
\text { liposomes, especially small monolayer vesicles (SUV). Its main } \\
\text { disadvantages are very low encapsulation efficiency, elimination of large } \\
\text { molecules, metal contamination from the probe tip, possible degradation of } \\
\text { phospholipids, and presence of MLV. } \\
\text { There are two sonication techniques: } \\
\text { (a) probe-tip sonication-the energy needed for lipid dispersion is very high. } \\
\text { Accumulation of energy at the tip of the sonicator probe can cause a local rise } \\
\text { in temperature. Therefore, the reaction vessel must be immersed in a water } \\
\text { or ice bath to control the temperature. During sonication (up to } 1 \text { h), more } \\
\text { than } 5 \% \text { of the lipids can deesterify. In addition, the use of a titanium-coated } \\
\text { probe causes contamination of the solution. } \\
\text { (b) sonication using a bath-liposome dispersion is placed in a bath-type } \\
\text { sonicator. Controlling the temperature of the dispersion is much easier in this } \\
\text { method than in the sonication using a probe. The sonicated liposomes can be } \\
\text { secured in a sterile vessel other than the probe or in an inert atmosphere. }\end{array}$ & {$[12,22]$} \\
\hline $\begin{array}{c}\text { French pressure cell: } \\
\text { extrusion }\end{array}$ & $\begin{array}{l}\text { The method involves injecting and pushing MLV vesicles through a small } \\
\text { hole. It is more advantageous than the sonication method because the } \\
\text { resulting liposomes are larger in size and resemble encapsulated substances } \\
\text { in form. The production of liposomes requires high temperatures and a } \\
\text { limited working volume. }\end{array}$ & {$[22,23]$} \\
\hline
\end{tabular}


Table 1. Cont.

Type of Method

Freeze-thawed liposomes

High-pressure

homogenization

homogenization
Membrane extrusion
Ether injection (solvent
vaporization)
vaporization)

Reverse-phase evaporation method
Description of the Method

Ref.

This method involves freezing the SUV liposomes for a short period of time and then leaving them to thaw for a long time. This technique leads to the dispersion of lipids and the formation of large monolayer vesicles (LUVs). Its greatest limitation is the increase in the phospholipid concentration and ionic strength of the medium.

The method is mainly used to obtain small vesicles (SUV) and to reduce the size of multilamellar liposomes.

A common industrial method for obtaining liposomes and consists of extruding the emulsion through a polycarbonate membrane with a uniform pore size $(\mathrm{N} \times 10,000$ Daltons). Lipids are pressed through the membrane, and then they are repeatedly circulated for a specific time, pressure, temperature, and flow rate. This technique requires less energy and fewer mechanical systems (which can cause additional fouling).

\section{SOLVENT DISPERSION METHOD}

Consists of the preparation of solutions of lipids dissolved in diethyl ether or ether-methanol mixture, which are then gradually injected into an aqueous solution of the material, which is encapsulated at 55 to $65^{\circ} \mathrm{C}$ or under reduced pressure. Systematic removal of the ether under vacuum leads to liposomes. The main disadvantage of this method is the heterogeneous particle size, ranging from 70 to $200 \mathrm{~nm}$. Compounds that are encapsulated are also exposed to organic solvents at high temperatures.

In this method, a lipid ethanol solution is rapidly injected into an excess of $0.16 \mathrm{M} \mathrm{KCl}$, resulting in the immediate preparation of MLV-type liposomes. A significant disadvantage of this method is the heterogeneous size of the particles obtained ( 30 to $110 \mathrm{~nm}$ ), very high dilution of the liposomes, and the need to remove ethanol.

The technique allows the production of liposomes with a high water to lipid volume ratio and allows the retention of a significant percentage of aqueous material. It involves the formation of inverted micelles that are shaped by sonication of a mixture of a buffered aqueous phase containing water-soluble molecules (which will be encapsulated in liposomes) and an organic phase (in which amphiphilic molecules are dissolved). In the next step, the organic solvent is removed, and thus the inverted micelles are transformed into a viscous state and gel form. Excess phospholipids in the environment ensure the formation of a complete bilayer around the residual micelles, which results in the formation of liposomes. Liposomes produced by this method can be made from multiple lipid preparations and have a lipid-to-water volume ratio four times higher than that of multilamellar liposomes.

\section{DETERGENT REMOVAL METHOD (REMOVAL OF UNENCAPSULATED MATERIAL)}

Detergents are used to solubilize the lipids at their critical micellization concentrations (CMC). These detergents are then removed by dialysis, which

Dialysis can be performed in dialysis bags immersed in buffer solutions that do not contain detergents. While the detergent is removed, the micelles easily bind to the phospholipids and form the LUV structure.

Detergent removal of mixed micelles

Detergent absorption is possible by shaking the mixed micelle solution with organic polystyrene absorbents. A major advantage of using these types of absorbents is that they can eliminate detergents with very low CMC.

\subsection{Applications of Liposomes}

Liposomes are mainly used for drug delivery. One method to improve the effectiveness of treatment is to use active substances encapsulated in carriers and administer them at concentrations that ensure delivery to the target sites without damaging healthy tissues. Liposomal drug carriers can provide great benefits compared to traditional drug substances. They protect the encapsulated drug from degradation and premature metabolization during 
release into the human body [14]. Encapsulation of active substances in liposomes can be achieved by two methods:

- $\quad$ passively - the active substance is encapsulated during liposome formation;

- $\quad$ actively - the active substance is encapsulated after the liposomes are formed.

Hydrophobic drugs, for example, amphotericin B, taxol, or annamycin, can be directly combined with liposomes during vesicle formation, and their absorption and encapsulation depend on drug-lipid interactions. It is possible to achieve $100 \%$ drug encapsulation efficiency, but it depends on the solubility of the drug in the liposome membrane [12]. Liposomes are used to deliver drugs approved by the Food and Drug Administration (FDA), like the anthracyclines Doxil (doxorubicin) and DaunoXome (daunorubicin), for the treatment of ovarian cancer, breast cancer, multiple myeloma, and sarcomas [26].

Numerous studies have led to "second generation liposomes", i.e., the structures with modified surfaces. They are obtained by using several types of particles, such as glycolipids or sialic acid (N-acetylneuraminic acid), as well as modified and unmodified dextrans [14]. Liposomes, due to the high risk of "uptake" by the reticuloendothelial system, are coated with a synthetic polymer, polyethylene glycol (PEG). The use of PEG prolongs the period of liposome circulation in blood $[21,27,28]$. Unfortunately, limitations to the use of liposomes include short lifespan, low encapsulation efficiency (mainly hydrophilic drugs), and rapid "uptake" [29]. It has been confirmed that drug encapsulation in liposomes or solid lipid nanoparticles increases their delivery to the brain; for some of them, this is the only chance to cross the blood-brain barrier. Liposomes are also used in gene therapy as non-viral vectors [30]. Currently, only positively charged liposomes are used for this purpose because the cationic surface allows complexes to form with the negatively charged DNA structure. The purpose of using liposomes as nonviral vectors is to deliver the unmodified gene to the target cell. Liposome vesicles have found wide application in the delivery of proteins and peptides into the cytoplasm of dendritic cells by endocytosis [31]. The main advantage of liposomes as gene carriers over non-viral vectors [30] is that they do not contain proteins, which eliminates a possible immune response. On the other hand, their disadvantage is that they can accumulate in a living organism and thus fail to perform their task. However, this disadvantage can be overcome by coating them with neutral or cationic phospholipids, as proposed by Miller and his team at Imperial College, London [32].

\section{Niosomes}

Niosomes are nanocarriers formed by the self-organization of nonionic surfactants in an aqueous environment, resulting in closed bilayer structures [33]. They are composed of a nonionic surfactant, cholesterol or its derivatives, and a charged molecule, surrounded by aqueous spaces, see Table 2.

Table 2. Compounds used to obtain niosomes.

\begin{tabular}{clll}
\hline & \multicolumn{2}{c}{ Type of Compounds } & \multicolumn{1}{c}{ Examples } \\
\hline & \multicolumn{1}{c}{ Alkyl ethers } & Alkyl glycerol ether, Hexadecyl diglycerol ether & [34] \\
\cline { 2 - 3 } Nonionic surfactant & Crown ethers & Alpha, omega-hexadecyl-bis(1-aza-18-crown-6)(Bola) & [35,36] \\
\cline { 2 - 3 } & Alkyl esters & Span 20, Span 40, Span 60, Span 80, Span 65, Span 85 & [37-43] \\
\cline { 2 - 3 } & Fatty acids & Stearic acid, palmitic acid \\
\cline { 2 - 3 } Lipids & Fatty alcohols & Stearyl alcohol, cetyl alcohol \\
\hline \multirow{2}{*}{ Charged molecule } & Block copolymers & Pluronic L64, Pluronic 105 \\
\cline { 2 - 3 } & Steroids & Cholesterol & [48,49] \\
\hline & Negative charge & Dicetyl phosphate, phosphatidic acid, lipoamino acid \\
\hline
\end{tabular}


Niosomes are classified based on their size or number of bilayers:

- $\quad$ small unilamellar vesicles (SUV);

- $\quad$ large unilamellar vesicles (LUV);

- multilamellar vesicles (MLV) [50].

The particle size of nonionic vesicles is in the sub-micron size range. For SUV vesicles, their size is $10-100 \mathrm{~nm}$, while the size of LUV vesicles is in the range of 100-3000 nm and MLVs are larger than $5 \mu \mathrm{m}$ [33]. Niosomes have a unique structure, and therefore it is possible to encapsulate hydrophilic and hydrophobic materials in the particle core and in the bilayer [51,52].

The introduction of cholesterol during the synthesis of niosomes improves the rigidity of the bilayer. This structure protects drug molecules from premature degradation and inactivation due to adverse immunological and pharmacological effects [53]. A comparison between liposomes and niosomes is shown in Figure 2.

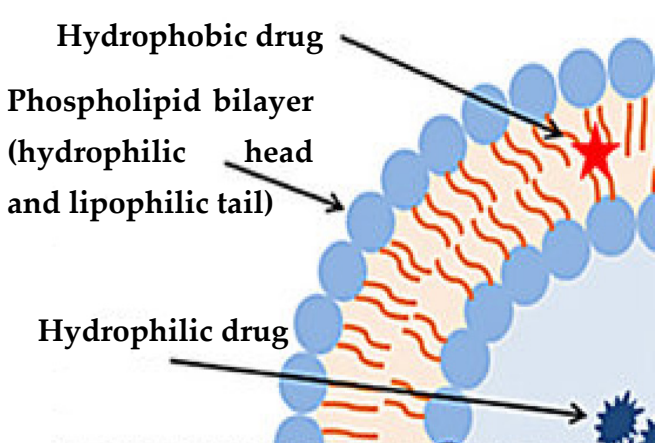

LIPOSOME

- vesicles made up of concentric bilayer of phospholipids;

size ranges from $0.01-1.00 \mu \mathrm{m}$;

expensive;

special storage condition are required.

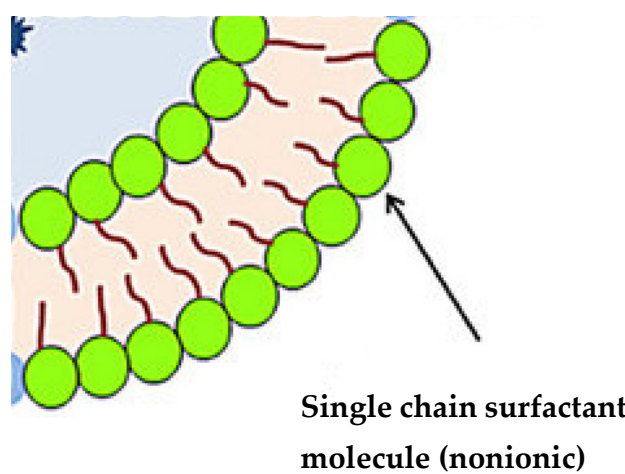

NIOSOME

- vesicles made up of surfactants with/without incorporation of cholesterol;

- $\quad$ size ranges from $0.01-0.1 \mu \mathrm{m}$; inexpensive;

no such special requirement.

Figure 2. Schematic of the structure of the liposome and niosome (modified from [54]; original paper under the terms of the Creative Commons CC BY-NC 3.0).

\subsection{Methods of Obtaining Niosomes}

The most important methods for obtaining niosomes are included in Table 3.

Table 3. Methods for obtaining niosomes.

\begin{tabular}{c}
\hline Type of Method \\
\hline $\begin{array}{c}\text { Thin-Film Hydration (TFH) } \\
\text { Method }\end{array}$
\end{tabular}

Description of the Method

Ref.

Initially, the TFH technique was used to synthesize liposomes, but over time, it was also used to obtain niosomes. In this method, surfactants and cholesterol are homogeneously dissolved in an organic solvent such as chloroform or a mixture of solvents. The solvent is completely evaporated using a rotary vacuum evaporator, resulting in a thin film on the inner surface of the flask. The resulting film is rehydrated using either water alone or phosphate-buffered saline (PBS), which usually contains the encapsulation drug. Once the rehydration is complete, MLV niosomes of various diameters are formed.

The SI technique involves dissolving the surfactant and cholesterol with diethyl ether or ethanol. The homogeneous solution is placed in a syringe pump and Solvent Injection (SI) Method introduced dropwise through a needle into an aqueous solution at a constant temperature (which is higher than the boiling point of the organic solvent). The residual solvent is removed by evaporation in a vacuum rotary evaporator. This process leads to monolayer vesicular niosomes of various sizes. 
Table 3. Cont.

\begin{tabular}{cl}
\hline Type of Method & \multicolumn{1}{c}{ Description of the Method } \\
\hline & The REV method was first presented by Szoka and Papahadjopoulos [26] in 1978 \\
as a technique to obtain LUV-type niosomes. It involves the preparation of two \\
phases, organic and aqueous. The organic phase usually consists of a mixture of \\
ether and chloroform, containing Span 60, cholesterol, and stearoylamine to \\
form the membrane. The aqueous phase consists of water or PBS in which the \\
drug is dissolved. The organic phase is mixed with the aqueous phase, and then \\
the whole mixture is vigorously shaken or subjected to ultrasound to obtain the \\
[REV) Method \\
emulsion. The next step of the process is to evaporate the organic phase using a \\
constant temperature vacuum evaporator, resulting in LUV-type niosomes.
\end{tabular}

Niosomes are obtained without the use of organic solvents. Surfactants, additives (e.g., cholesterol), and the buffer (pH 7.4) are added into a three-neck round-bottom flask. The flask is placed in a water bath to control the

The Bubble Method temperature. The dispersion of surfactants and additives occurs at $70{ }^{\circ} \mathrm{C}$. To obtain a homogeneous dispersion, a high-speed homogenizer is first used, stirred for $15-30 \mathrm{~s}$, and then bubbled with a $70^{\circ} \mathrm{C}$ nitrogen gas. Nitrogen gas is passed through a sample of homogenized surfactants resulting in the formation of large unilamellar vesicles.

It is an improved and much simpler method of niosome preparation derived from the TFH technique. MLV-type niosome suspension prepared by the TFH method is frozen in liquid nitrogen and then thawed several times in a short

Freeze and Thaw Method time using a water bath.

It was first described by Kirby and Gregoriadis [34]. SUV-type niosomes prepared by the TFH technique are used to form MLVs. Small monolayer

Dehydration-Rehydration vesicles (SUVs) are separated by centrifugation, and then SUV-type niosomes

Vesicles (DRV) Method containing the drug are added to the aqueous phase. The resulting suspension was lyophilized overnight. After the dried product was rehydrated, multilamellared niosomes formed.

It is a new method to obtain niosomes, and it was first presented by Manosroi et al. [60]. Surfactant, cholesterol, PBS with glucose and ethanol are placed in a glass cell of a constant volume and two windows. $\mathrm{CO}_{2}$ is then introduced into the cell while maintaining a pressure of 200 bar and a temperature of $60^{\circ} \mathrm{C}$.

Supercritical Carbon Dioxide Fluid (scCO2) Method Niosomes are obtained after $30 \mathrm{~min}$ of stirring all ingredients on a magnetic stirrer and then lowering the pressure. With this method, LUV-type niosomes with sizes ranging from 100 to $440 \mathrm{~nm}$ can be obtained. The greatest advantage of this method is the one-step process, which does not require the use of toxic, flammable, and volatile organic solvents.

The technique has been recently developed and is used to obtain nanocarriers, including niosomes. The method involves the addition of surfactants, cholesterol, and active ingredients to an aqueous phase (such as PBS). The

Heating Method (HM) solution is prepared by stirring and heating the aqueous phase, and then a $3 \%$ $w / v$ (weight/volume) polyol such as glycerol is added to the resulting solution. The main advantage of the method is that there is no need for toxic and volatile organic solvents.

\subsection{Applications of Niosomes}

Niosomes are promising carriers for many pharmaceuticals and may be used in diagnostics. Due to their non-ionic nature, they provide high biocompatibility and low toxicity [33].

Initially, niosomes were synthesized for cosmetic purposes, but over time, they have been proposed for use in the pharmaceutical industry for potential drug delivery. Studies of niosomes such as unilamellar or multilamellar nanoparticles are concerned with determining optimal drug encapsulation methods and the kinetics of loading and release of the active ingredient. The ability of niosomes to improve the bioavailability and efficacy of 
drugs has attracted the attention of researchers due to their potential use in the treatment of severe inflammation and various types of cancer, among others [33].

When used as novel drug delivery systems, niosomes counteract the poor penetration of chemotherapeutics into cancer cells and offset the side effects of chemotherapeutics on healthy cells. They are used in the treatment of melanoma, lung cancer, breast cancer, and ovarian cancer [59], and they are also effective carriers of antibiotics and anti-inflammatory drugs. In addition, niosomes have been synthesized to improve poor drug penetration through the skin and poor drug retention in the skin. Studies conducted for rifampicin, a broad-spectrum antibiotic, have shown that niosomes used as carriers for this drug provide continuous and prolonged release [61].

Niosomes are also being tested as carriers of anti-inflammatory drugs, especially nonsteroidal anti-inflammatory drugs (NSAIDs), which are known to cause adverse side effects such as mucosal irritation. The topical application of NSAID-loaded niosomes improves drug permeability. Studies have been carried out on niosomes containing ammonium aglycyrrhizinate (AG), using several surfactants and cholesterol at different concentrations [62]. The drug entrapment efficiency, lipid anisotropy, cytotoxicity of this active ingredient delivery system, and its skin tolerance were evaluated. AG-loaded niosomes showed no toxicity, and their use improved the anti-inflammatory effect of the drug. In addition, enhancement of the anti-inflammatory effect of drugs delivered by niosomes on chemically induced skin erythema in humans has been reported. These nanoparticles are also used to deliver antiviral drugs, mainly against HIV [61].

\section{Lipid Nanoparticles}

Lipid matrix nanoparticles (LNPs), which are used as nanocarriers, were first synthesized in the early 1990s [63]. Their synthesis was a breakthrough in the search for a new generation of nanocarriers. Due to the wide possibilities of their surface modifications, they can be used to increase drug bioavailability, enable controlled release of active ingredients, improve intracellular permeability, and enable control of drug delivery to target sites [1].

Lipid-based nanoparticles are colloidal particles consisting of a lipid matrix stabilized with surfactants. They are stable at room temperature [64], their size ranges from $40 \mathrm{~nm}$ to $1000 \mathrm{~nm}$, and they are called lipid colloidal carriers [65,66]. Typically, LNP carriers consist of solid lipids, surfactants, cosurfactants (if necessary), and active ingredients. The composition of the lipids is crucial [67]. The most commonly used lipids are fatty acid esters, fatty alcohols, acylglycerols, and mixtures of acylglycerol esters. Examples of lipids used in LNP synthesis are summarized in Table 4.

Table 4. Selected lipids used for LNP synthesis and their structure.

\begin{tabular}{|c|c|}
\hline Type of Lipid & Structure \\
\hline Monoacylglycerols & $\begin{array}{l}\mathrm{CH}_{2}-\mathrm{O}-\mathrm{CO}-\mathrm{R} \\
\mathrm{CH}_{\mathrm{CH}}-\mathrm{OH} \\
\mathrm{CH}_{2}\end{array}$ \\
\hline Diacylglycerols & $\begin{array}{l}\mathrm{CH}_{2}-\mathrm{O}-\mathrm{CO}-\mathrm{R} \\
\underset{\mathrm{CH}}{\mathrm{C}}-\mathrm{O}-\mathrm{CO}-\mathrm{R} \\
\mathrm{CH}_{2}-\mathrm{OH}\end{array}$ \\
\hline Triacylglycerols & $\begin{array}{l}\mathrm{CH}_{2}-\mathrm{O}-\mathrm{CO}-\mathrm{R} \\
\mathrm{CH}-\mathrm{O}-\mathrm{CO}-\mathrm{R} \\
\mathrm{I} \mathrm{CH}_{2}-\mathrm{O}-\mathrm{CO}-\mathrm{R}\end{array}$ \\
\hline Fatty acids & $\begin{array}{l}\mathrm{R}^{\mathrm{l}}-\mathrm{COOH} \\
\mathrm{R}^{2}-\mathrm{COOH} .\end{array}$ \\
\hline
\end{tabular}

where, $R, R^{1}, R^{2}$ are alkyl chains. 


\subsection{Solid Lipid Nanoparticles (SLNs)}

Solid lipid nanoparticles (SLNs) are colloidal carriers that were first synthesized in 1991 as an alternative to liposome, emulsion, and polymeric micro- and nanoparticle-based systems [68]. SLNs combine the advantages of traditional colloidal carriers and avoid some of their major drawbacks [69]. They are stable at room temperature and at human body temperature $[70,71]$. SLNs usually have a spherical shape and a diameter in the range of 50-1000 nm. Solid lipid nanoparticles consist of a core of solid lipids in which a bioactive component is embedded, and this structure is stabilized by a surfactant coating (Figure 3).

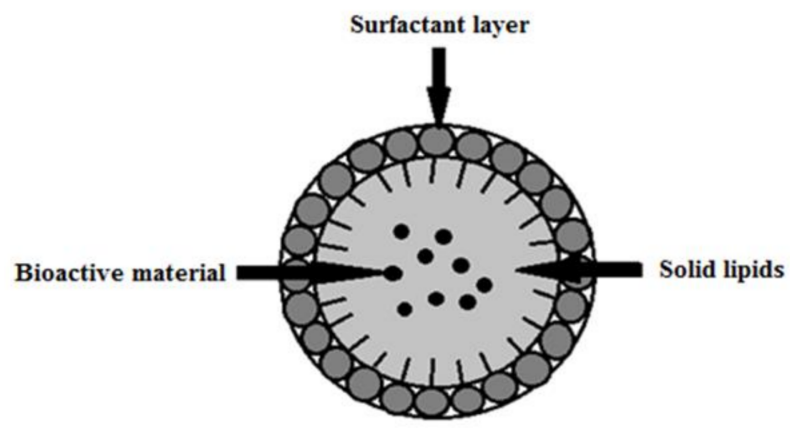

Figure 3. Structure of a solid lipid nanoparticle (SLN) stabilized by surfactant coating/layer (modified from [1]; original paper under the terms of the Creative Commons CC BY-NC 3.0).

Depending on the structure, lipids are mainly divided into fatty acids, fatty esters, fatty alcohols, triacylglycerols, and partial glycerides. Ionic and nonionic polymers (Pluronic ${ }^{\circledR}$, such as F68 and F127 (e.g. Sigma-Aldrich Sp. z.o.o (Poznań, Poland)), surfactants, and organic salts are used as emulsifiers [1]. The most attractive features of SLNs are:

- $\quad$ high physical stability;

- the possibility of large-scale synthesis;

- biocompatibility;

- lack of biotoxicity;

- increased stability of the active ingredient;

- low risk of chronic or acute intoxication;

- $\quad$ no need for organic solvents in synthesis [71];

- the ability of controlled release of active ingredient [72];

- $\quad$ ability to block UV radiation (UV blocking is characteristic of some lipids);

- the ability to act as occlusive compounds;

- $\quad$ the ability to protect unstable compounds from chemical degradation [73].

Potential disadvantages associated with SLNs are limited drug loading capacity, the potential for drug leakage (uncontrolled release), and crystallization during formulation storage [1].

\subsection{Nanostructured Lipid Carriers (NLCs)}

Nanostructured lipid carriers are the second generation of solid lipid nanoparticles that have been designed to eliminate the SLN limitations associated with having to use only solid lipids for their synthesis. Müller et al. [74] have shown that it is possible to overcome this limitation by adding liquid lipids that alter the crystal structure of the lipid matrix $[74,75]$. NLCs offer a number of additional benefits, such as greater drug loading capability and higher physicochemical stability attributed to a mixture of solid and liquid lipids [76,77]. Nanostructured lipid carriers are characterized by a partially crystallized lipid matrix with a poorly ordered structure, which significantly reduces the risk of drug leakage (uncontrolled release) during storage [78].

The technology for obtaining NLCs is identical to that of SLNs. Nanostructured lipid carriers can be produced by the HPH (High-Pressure Homogenization) method, and this process can result in particle dispersions with solid content in the range of 30-80 wt.\% [69]. 
Depending on the composition of the lipid-oil mixture, three types of NLC structures can be distinguished (Figure 4) [2]:

- imperfect crystal structure;

- amorphous structure;

- multiple structure.

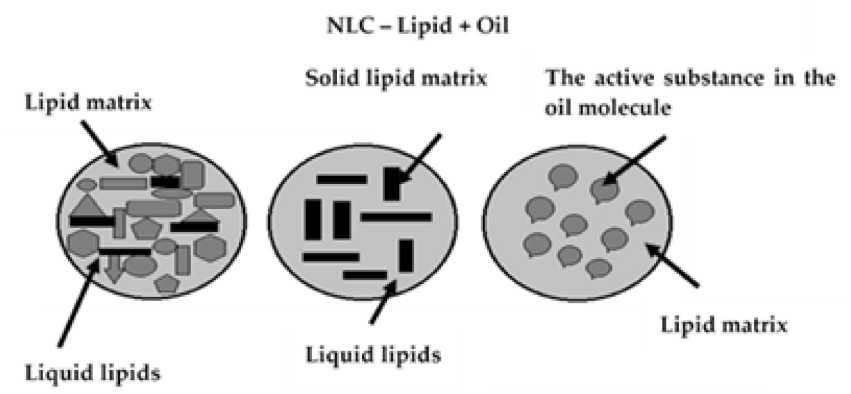

$\begin{array}{lll}\text { (I) Imperfect Crystal } & \text { (II) Amorphous } & \text { (III) Multiple }\end{array}$

Figure 4. Structure types of nanostructured lipid carriers: (I) imperfect crystal, (II) amorphous, (III) multiple (modified from [2]; original paper under the terms of the Creative Commons CC BY).

NLCs cannot be used to encapsulate active ingredients and drugs with a hydrophilic character. In contrast to SLNs, the NLC matrix consists not only of solid lipids but also contains liquid lipids (oils), water, and surfactants. SLN is mixed with oils in ratios ranging from 70.0:30.0 to 99.9:0.1. Higher amounts of oils can be used in the NLC multilayer structure. The entire system is stabilized with surfactants $(0.5-5.0 \%$ by weight). The compounds most commonly used for NLC synthesis are [1,2]:

\section{* Solid lipids}

$>\quad$ glyceryl behenate (e.g., Compritol ${ }^{\circledR} 888$ ATO, Gattefosse (Saint-Priest, France));

$>$ stearic acid;

> glyceryl monostearate (GMS);

$>$ cetyl palmitate;

> glyceryl palmitostearate (e.g., Precirol ${ }^{\circledR}$ ATO 5 Gattefosse (Saint-Priest, France));

* Liquid lipids

$>$ soybean oil;

$>\quad$ oleic acid (OA);

- isopropyl myristate;

$>\quad \alpha$-tocopherol/vitamin E;

$>$ squalene.

\section{* Surfactants}

$>\quad$ polyoxyethylene (20) sorbitan monolaurate (e.g., Tween ${ }^{\circledR} 20$ Sigma-Aldrich Sp. z.o.o (Poznań, Poland));

$>\quad$ polyoxyethylene (80) sorbitan monooleate (e.g., Tween ${ }^{\circledR} 80$ Sigma-Aldrich Sp. z.o.o (Poznań, Poland));

$>\quad$ polyvinyl alcohol (PVA);

$>$ ecithin;

$>\quad$ Solutol ${ }^{\circledR}$ HS 15; (e.g., Sigma-Aldrich Sp. z.o.o (Poznań, Poland));

$>$ polyoxyl castor oil.

The NLC core with an imperfect crystal structure (Figure 4I) consists of a mixture of solid and liquid lipids. The structural differences between these two components contribute to the modification of the packed structure of the solid lipids. Crystallization processes of the imperfect matrix result in a disordered structure, offering free space that can be occupied by the active component [1,2,74]. 
NLCs with an amorphous structure have a core of an amorphous matrix formed by mixing large amounts of oil with solid lipids. Usually, drugs are much more soluble in liquid than in solid lipids, which results in the production of NLCs with high liquid lipid content. In the fabrication of NLCs with an amorphous structure, the liquid lipid particles (nanoemulsions) are cooled to room temperature to initiate crystallization and solid particle formation. In the amorphous type of structure, the oil concentration is high, and after cooling, crevices form where solid and liquid lipids can mix (Figure 4II). NLCs are mostly found in the amorphous state [79]. The third type of NLC with multiple structures is also called the amorphous type. In this method of NLC preparation, lipids are mixed to prevent crystallization. In NLC with multiple structure, the lipid matrix remains solid but in an amorphous state (Figure 4III) [80]. Upon cooling, phase separation occurs, and oil nanoparticles precipitate. The active ingredient is dissolved in the liquid lipid so that it is protected from the aqueous environment $[69,81]$.

\subsection{Methods of Obtaining Nanoparticles}

The content of this section is limited to a discussion of methods for the synthesis of lipid nanoparticles. The main methods for this synthesis are high-pressure homogenization (HPH) [70] and the microemulsion method [82]. Other cheaper and easier methods have also been proposed, such as dispersion using a high-speed stirrer or ultrasound, solventbased emulsification/evaporation technique, or membrane squeezing method [71].

\subsubsection{High-Pressure Homogenization (HPH)}

High-pressure homogenization is the most efficient method for lipid nanoparticle synthesis and has been used for many years for microemulsion production and largescale production of lipid nanoparticles of both SLN and NLC types $[8,80]$. The greatest advantages of this technique are the very short production time and the easy transfer of production from laboratory scale to large-scale production [83].

Despite its many advantages, high-pressure homogenization is an energy-intensive process and causes an increase in sample temperature, which is not beneficial for heatsensitive compounds [80]. In high-pressure homogenizers, a mixture of lipids, water, surfactant, and the active ingredient is forced through very small diameter tubes (usually a few microns) at pressures ranging from 100 bar to 2000 bar. Over short distances, the liquid can reach velocities of more than $1000 \mathrm{~km} / \mathrm{h}$. As a result of high cavitation and shear forces, the liquid lipid particles are fragmented to a submicrometer size. This method can achieve lipid nanodispersion even at lipid concentrations of up to $40 \%$ by weight [84]. There are two types of high-pressure homogenization: hot and cold. Schemes of both processes are shown in Figure 5. In both methods, in the initial stage, the active ingredient is introduced into the lipid particles by dissolution or dispersion in molten lipid [85].

\section{Hot Homogenization HPH}

Hot homogenization (Figure 5) is performed at temperatures above the melting point of lipids and is often considered emulsion homogenization. A high-speed stirrer is used to obtain a pre-emulsion containing the active ingredient, the molten lipid, and the aqueous phase of the emulsifier (5-10 ${ }^{\circ} \mathrm{C}$ above the melting point of the lipid). The quality of the final homogenization product depends largely on the quality of the pre-emulsion, which should be made of particles of a few micrometers in size. Too high a temperature can lead to degradation of the active ingredient and/or the carrier. The homogenization process can be repeated several times. Homogenization under increased pressure can lead to an increase in the emulsion temperature of up to approximately $10{ }^{\circ} \mathrm{C}$ for every 500 bar of pressure applied. Generally, satisfactory results are obtained after 3 to 5 cycles of homogenization at 500 to 1500 bar pressure. Increasing the pressure or the number of cycles increases the size of the lipid nanoparticles as a result of coalescence occurring due to their high kinetic energy. The final product of hot homogenization is a nanoemulsion in the liquid phase. Particulate solids are obtained after the nanoemulsion is cooled to room temperature or 
below. Lipid crystallization can take a very long time (up to several months) due to the small size of the particles and the presence of emulsifiers [85].

\section{Cold Homogenization HPH}

This process is ideal for highly sensitive hydrophilic compounds [86]. Cold homogenization (Figure 5) is performed with solid lipids. In this process, proper temperature control is particularly important to maintain the solid lipids since the temperature can increase significantly during the homogenization process. The cold homogenization method was developed to overcome the three main disadvantages of hot homogenization [87]:

- $\quad$ high temperature-induced degradation of the active ingredient;

- the complexity of the nanoemulsion crystallization step leading to the modification of lipid nanoparticles;

- the degradation of the active ingredient in the aqueous phase during the homogenization process.

The first stage of cold homogenization is the same as that of the hot homogenization process and involves the solubilization or dispersion of the active ingredient in the molten lipid. In the next step, the molten lipid containing the active ingredient is immediately cooled with dry ice or liquid nitrogen. The efficiency of homogenization of the active ingredient inside the lipid carrier is favored by a significant drop in temperature. The solid lipid containing the active substance is crushed in a mortar into 50-100 microns particles. The low temperatures of the process enhance the brittleness of the lipids, which promotes their efficient pulverization. The solid lipid microparticles are dispersed in a cooled emulsifier solution. The suspension thus obtained is homogenized under increased pressure at room temperature or below. Cold homogenization allows obtaining lipid particles larger than those obtained in the case of hot homogenization. At the same time, it eliminates the risk of adverse effects of high temperatures without taking into account the high temperature of the first step of introducing the active substance into the molten lipid $[1,83,85]$.

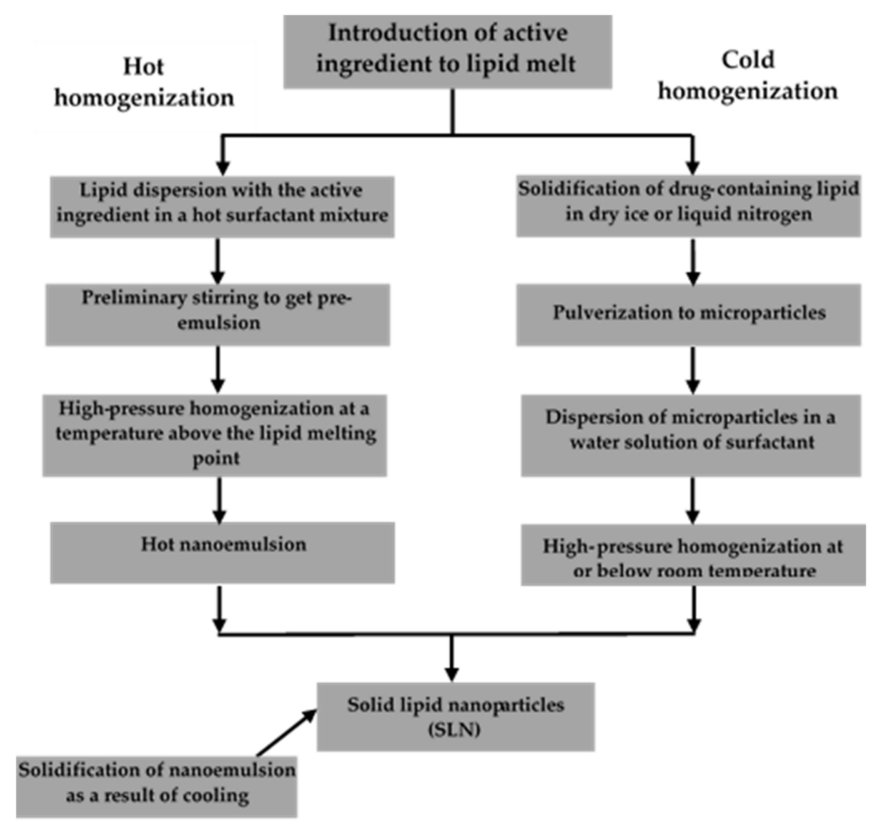

Figure 5. Hot and cold homogenization scheme (modified from [1]; original paper under the terms of the Creative Commons CC BY-NC 3.0).

\subsubsection{Microemulsion Method}

The widely used microemulsion method to produce lipid nanoparticles has been described for the first time by Gasco et al. [81]. The method involves melting a lipid 
(or lipid mixture) and heating the aqueous phase (containing surfactant) to the same temperature. To obtain microemulsions containing solid lipids (at room temperature), the manufacturing process should be carried out at temperatures higher than the melting point of the lipid. The microemulsion is prepared by adding an aqueous solution to the lipid phase upon continuous slow stirring. Lipid nanoparticles are obtained by dispersing the microemulsion in cold water $\left(2-10^{\circ} \mathrm{C}\right)$ by continuous stirring. Finally, the system is washed with distilled water, filtered (to remove larger particles), and can be lyophilized to remove excess water [88].

The most common emulsifiers soy phosphatidylcholine, polysorbate 20 , polysorbate 60 , while the most commonly used co-emulsifiers are alcohols. The method allows nanoparticles to be obtained under mild temperature conditions. However, the technique has numerous drawbacks, including the need for relatively high concentrations of surfactants and a high dilution of the particle suspension $[1,71,89,90]$. The scheme of the process is shown in Figure 6.

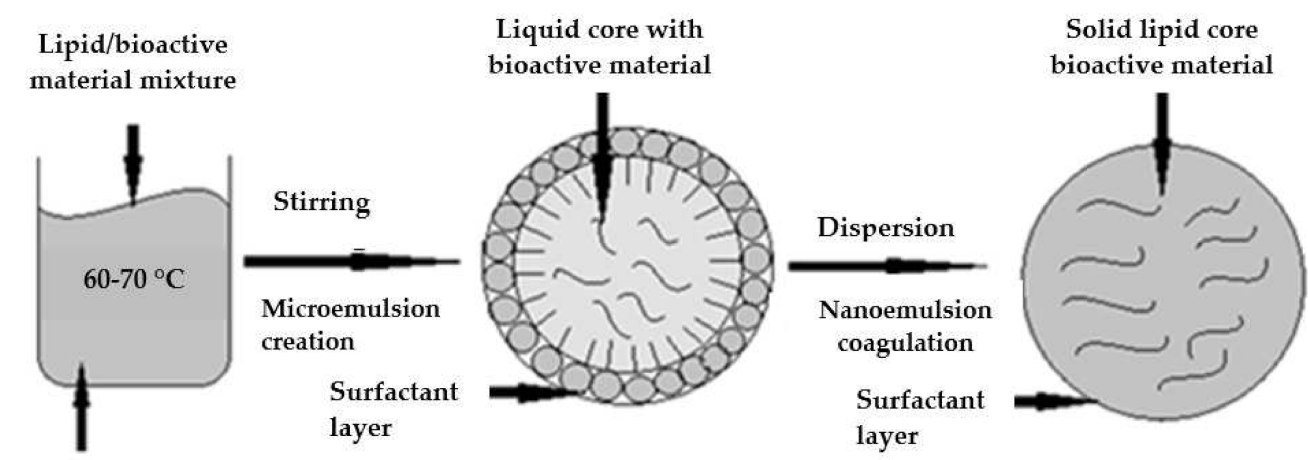

Surfactants mixture

Figure 6. Structures formed by microemulsion fabrication of lipid nanoparticles (modified from [1]; original paper under the terms of the Creative Commons CC BY-NC 3.0).

\subsubsection{Solvent-Based Emulsification/Evaporation Technique}

The method of obtaining nanodispersions by precipitation of $\mathrm{o} / \mathrm{w}$ emulsions was first described by Sjörström and Bergenståhl [91]. The technique involves the formation of an oil-in-water emulsion with a partially miscible solvent (of low toxicity), which is then emulsified in the aqueous phase. The whole process is based on the miscibility of water with this type of solvent, which contains active substances. Once formed, the $\mathrm{o} / \mathrm{w}$ transition emulsion is transferred to water (during continuous mixing), which is the cause of the diffusion of the solvent into the external phase. In this step, the dispersed phase solidifies, and nanoparticles are formed. The solvent can be further removed by evaporation under reduced pressure [92,93]. The main advantages of this technique are versatility, reproducibility, and ease of implementation, as it does not require large energy inputs and does not expose drugs to temperature stress conditions. The disadvantage of the process is the need to purify and thicken the lipid nanoparticle dispersion [93].

\subsubsection{Emulsification-Solvent Evaporation}

Lipids are dissolved in organic solvents immiscible with water (e.g., cyclohexane or chloroform) and dispersed in the aqueous phase. The lipid solution forms an emulsion in the aqueous surfactant solution after continuous stirring. The organic phase is then evaporated, causing the lipids to precipitate. The disadvantages of this method are the need for organic solvents and an additional evaporation step [85,94].

\subsubsection{Sonication/Ultrasound}

This is a dispersion-based method and involves melting the lipid matrix (with the drug) at a temperature of $5-10{ }^{\circ} \mathrm{C}$ above its melting point. The molten lipid is then dispersed in an aqueous phase containing a surfactant (at the same temperature) upon rapid stirring 
to form an emulsion. The entire mixture is subjected to ultrasound irradiation to reduce the size of the droplet and gradually cooled to form the nanoparticle dispersion [82]. The most significant advantage of this method is the use of readily available laboratory equipment [73]. Obtaining lipid nanoparticles requires long sonication times, which increases the risk of contaminating the emulsion with metal filings from the probe. Furthermore, the presence of highly polydisperse formulations with a large number of microparticles can be problematic for some lipid nanoparticle-based drug delivery routes [95,96].

\subsubsection{Solvent Injection (or Solvent Displacement)}

This method involves dissolving the lipid matrix in a solvent mixed with water and rapidly injecting the mixture through a needle into the mixed aqueous phase containing the surfactant. The technique is easy to implement, versatile, and effective in obtaining lipid nanoparticles. Nevertheless, the use of organic solvents is its drawback [97].

\subsubsection{Phase Reversal}

This method does not require the use of solvents. It involves mixing individual components of the formulation: lipid matrix, drug, water, and surfactant on a magnetic stirrer using 3 temperature cycles $\left(85-60-85-60-85^{\circ} \mathrm{C}\right)$. The mixture is then subjected to a sudden temperature change; that is, it undergoes thermal shock by diluting the mixture with cold distilled water, resulting in the formation of lipid nanoparticles. The advantage of this technique is that there is no need for organic solvents and that heating takes only a short time. However, it is a time-consuming process [88].

\subsubsection{Membrane Contractor}

In this method, the molten lipid is forced through a porous membrane under increased pressure, while lipid droplets are deposited on the other side of the membrane. The aqueous phase circulates inside the membrane module and removes the lipid droplets. The method is very simple and has no major drawbacks, and the particle size can be controlled using membranes with different pore sizes [98,99].

To summarize up the advantages and disadvantages for the production of SLN/NLC methods are presented in Table 5.

Table 5. Pros and cons of different lipid nanoparticles production.

\begin{tabular}{|c|c|c|}
\hline Methods & Advantages & Disadvantages \\
\hline Hot HPH & $\begin{array}{l}\text { versatile, avoid organic solvent, easy scalability, and } \\
\text { short production time }\end{array}$ & $\begin{array}{l}\text { high temperature can cause degradation, } \\
\text { conformational changes in protein, changes in } \\
\text { particle size (coalescence of particles), burst release } \\
\text { due to high emulsifiers concentration }\end{array}$ \\
\hline Cold HPH & $\begin{array}{l}\text { avoid thermal exposure of the drug; good for } \\
\text { temperature-labile drugs or hydrophilic drugs }\end{array}$ & higher Polydispersity index (PDI) \\
\hline Microemulsion & $\begin{array}{l}\text { no need for specialized equipment (robust) and low } \\
\text { energy for production }\end{array}$ & $\begin{array}{l}\text { high concentrations of surfactants and co-surfactants, } \\
\text { presence of large amounts of water in the system }\end{array}$ \\
\hline $\begin{array}{l}\text { Emulsification-solvent } \\
\text { evaporation }\end{array}$ & $\begin{array}{l}\text { avoid heat during production thus useful for } \\
\text { thermolabile drugs; simple procedure }\end{array}$ & solvent residues \\
\hline $\begin{array}{l}\text { Emulsification/ultrasound/ } \\
\text { sonication }\end{array}$ & $\begin{array}{l}\text { no organic solvent residue, no burst release, high } \\
\text { lipid concentration, versatile, avoid use of organic } \\
\text { solvent, better drug loading than } \mathrm{HPH}\end{array}$ & $\begin{array}{l}\text { metallic particle contamination, broader particle size } \\
\text { (higher PDI) }\end{array}$ \\
\hline Emulsification-solvent diffusion & $\begin{array}{l}\text { simple procedure, fast drug release (drawback when } \\
\text { slow release is required) }\end{array}$ & $\begin{array}{l}\text { low lipid content, low EE and DL, organic solvent } \\
\text { residue, lack of scale-up }\end{array}$ \\
\hline Membrane Contactor & $\begin{array}{l}\text { simple method, control of particle size by selection of } \\
\text { process parameters (size of membrane pores) }\end{array}$ & limited scaling up possibility \\
\hline
\end{tabular}

\subsection{Applications of Lipid Nanoparticles}

Nanotechnology is one of the most intensively developing fields of science, mainly because of the great prospects of nanoparticle applications, especially in medicine. Their 
use as drug carriers is particularly promising in the diagnosis and treatment of various diseases [100]. Lipid-based nanocarriers are of increasing interest, mainly due to their biocompatibility with the human body. Due to their lipophilicity, they are able to overcome physiological barriers, of which the most important is the blood-brain barrier, even without modifying the particle surface. Nanoparticles can be carriers of proteins, peptides, antibodies, and contrast substances $[3,101]$. The undoubted advantages of nanocarriers are their easy and cheap production methods and the possibility of large-scale production [10,32].

\subsubsection{Solid Lipid Nanoparticles (SLNs)}

Over the past few years, solid lipid nanoparticles (SLNs) have found applications in the medicine, pharmaceutical, food, and cosmetic industries [71]. Solid lipid nanoparticles are used in the pharmaceutical industry for controlled drug release and to increase the bioavailability of an active ingredient by altering the dissolution rate. SLNs are also used in parenteral therapies (intramuscular, intravenous injections) [72,102], for oral administration [103], rectal [104] and ocular [105].

The increase in the number of people suffering from cardiovascular diseases, including hypertension, cancer, and obesity, has influenced the development of many types of healthy diets based on the intake of dietary supplements. Bioactive substances isolated from animal or plant material are usually perishable, such as carotenoids, which are insoluble in water. The problem faced by manufacturers of specialty foods is the incorporation of lipophilic bioactive ingredients [71]. Solid lipid nanoparticles have proven to be a very good solution.

SLNs have been used successfully as carriers for drugs with protein and polypeptide structures [70,72]. Proteins are natural molecules isolated from oligopeptides which are the basic building blocks of living organisms, while oligopeptides are organic chemical compounds composed of two or more amino acids linked by a peptide bond. Before the use of SLNs, there was virtually no effective way to deliver drugs based on proteins or peptides. By incorporating drugs with protein or peptide structures into SLNs, it has become possible to increase their stability and delivery efficiency to the target site. Therapeutically important polypeptides incorporated into SLN carriers are calcitonin, cyclosporin A, insulin, LHRH, and somatostatin. In contrast, HBs (hepatitis B) and malaria antigens are important protein antigens. The model protein drugs delivered with SLN are bovine serum albumin and lysozyme [106]. It has been reported that SLNs are effective carriers of doxorubicin and tobramycin into the brain. Importantly, SLNs carrying these drugs are capable of crossing the blood-brain barrier [107-110], a physical and enzymatic barrier between blood vessels and neural tissue. The barrier protects the central nervous system from pathogens and controls the selective transport of certain molecules from blood to cerebrospinal fluid [111,112]. The use of pure drugs for therapies that require passage across this barrier, without support from a carrier, is ineffective, and drugs encapsulated in SLNs are able to do this. SLNs are used as carriers for chemotherapeutic substances that would otherwise have very little delivery to cancer cells [113]. The low solubility of drugs in water, their poor bioavailability, and low therapeutic index (tells how many times the lethal dose is greater than the effective dose) determine their low efficacy. Furthermore, increased resistance to cytostatics also contributes to the ineffectiveness of classical chemotherapy [114,115]. Due to the attachment of specific ligands to SLN-type carriers, it is possible for them to bind directly to the appropriate receptor located in tumor cells and simultaneously release the active substance into the tumor cell [116]. SLNs used as carriers of therapeutic substances provide an opportunity to increase the effectiveness of therapy [113].

\subsubsection{Nanostructured Lipid Carriers (NLCs)}

Nanostructured lipid carriers (NLCs) are capable of delivering drugs in a number of ways: topical application, oral application, in the lungs, eyes, and brain [117].

In dermatology, topical application, directly to the skin lesions, is the preferred mode of application because it mitigates side effects that can occur after oral and parenteral 
administration of drugs. In addition, the high concentration of the drug is maintained at the desired site for a long time. A major challenge for researchers was the low permeability of the drug through the stratum corneum, which is a barrier to toxins, molecules, and therapeutic substances. In dermatological applications, NLC offers the opportunity to be used in conventional creams and emulsions to provide controlled release and protection of the active ingredient and to minimize the risk of skin irritation. When drugs combined with NLC were used, an increase in their release rate was observed, regardless of the introduction of different emulsifiers during their synthesis [117]. It has been confirmed that the use of drugs encapsulated in NLCs provides a longer release time of the active ingredient and the whole system is not toxic under different therapeutic conditions. Examples of drugs that have been used in an encapsulated form in NLC are podophyllotoxin [118] and anti-inflammatory drugs such as flurbiprofen [119], indomethacin [120], celecoxib [116], N-palmitoyl-ethanolamine [121], etc.

Oral administration is the easiest way to administer a drug because it is painless and allows accurate dosage control. However, many drugs are poorly soluble and poorly bioavailable after oral administration due to various chemical, physical, and enzymatic barriers in the gastrointestinal tract. New drug delivery systems have been developed to overcome limitations, increase therapeutic efficacy (which would allow dose reduction), and mitigate side effects. The use of NLC increases the solubility of the active ingredient and enhances its permeability and bioavailability by protecting the drug from physiological $\mathrm{pH}$ and enzymatic degradation $[122,123]$. In the gastrointestinal tract, lipids from NLCs are partially digested in the stomach and then degraded in the small intestine to diacylglycerols and free fatty acids. Due to the presence of lipids, drugs encapsulated in NLCs remain longer in the stomach and colon, increasing drug absorption. NLCs stimulate bile secretion, which facilitates micelle formation [124].

A very promising and noninvasive route of drug delivery is inhalation through the lungs. It can be used for both local and systemic effects. The advantage of this route of drug delivery is the rapid absorption associated with the large lung surface area (nearly $100 \mathrm{~m}^{2}$ ) and the slow metabolism of the drug due to low enzymatic activity. It has proved promising in the treatment of cancer, metabolic problems, diabetes, chronic pain, infections, and autoimmune diseases $[125,126]$. In this route of administration, NLC provides:

- $\quad$ protection from degradation;

- $\quad$ homogeneous distribution of the drug in the alveoli;

- $\quad$ prolonged release time of the active substance;

- $\quad$ increased solubility of the active ingredient;

- $\quad$ reduced/mitigated side effects [127].

Barriers to the effectiveness of inhaled drugs include the geometry of the airways, moisture, and the presence of macrophages in the alveoli. The efficacy of the drug also depends on the size of the NLC, the homogeneous distribution of the drug in the lungs, its dose, the precipitation of the site, and the type of disease [128]. NLCs, like other inhaled formulations, must be nontoxic, biocompatible with the human body, nonirritating, and have an appropriate $\mathrm{pH}(3.0-8.5)$ [2].

Due to its unique anatomy and physiology, the eye is one of the best-protected organs in the human body. Drug delivery to this organ, especially to its posterior part, is very difficult due to the presence of various barriers: cornea, sclera and retina, blood-water, and blood-retina. Topical administration is non-invasive and very effective, especially in the anterior part of the eye. However, drug bioavailability is low, mainly due to the short residence time in the target tissue and the presence of anatomical barriers. The penetration of active substances into the posterior part of the eye is less than $5 \%$; therefore, other more invasive routes of drug administration are used, such as injections into the vitreous body and subconjunctiva, but they can cause infection, bleeding, and even loss of vision $[129,130]$. Drugs that have been successfully injected into the back of the eye include triamcinolone acetonide, mangiferin, voriconazole, cyclosporine A, or tobramycin [131]. 
The incidence of central nervous system diseases, such as Alzheimer's and Parkinson's disease, strokes, brain cancer, epilepsy, and bran infections, has increased significantly in recent decades. Their effective treatment is challenging, as almost $98 \%$ of the proposed drugs cannot cross the blood-brain barrier [83]. NLCs have been shown to be effective in delivering drugs to the brain because their retention in brain blood vessels was much higher than that of pure drugs. NLC surface functionalization with polysorbate 80, polyethylene glycol (PEG), low-density ligands (transferrin, lactoferrin, lipoprotein), low-density lipoprotein (LDL), and OX26 antibodies facilitate passage through the blood-brain barrier and delivery of the drug to the brain [132]. NLCs are preferred to SLNs due to their smaller size and potential for higher drug loading, although there has been no sufficient evidence to support the efficacy of the former [83].

Recently, it has been demonstrated that methotrexate encapsulated in NLC can be introduced intradermally into pathologically affected joints [133]. The efficacy of methotrexate incorporated into NLC is evidenced by reduced levels of various inflammatory markers and bone degrading enzymes. Another drug administered in NLC is flurbiprofen, which is used to treat inflammatory joint conditions. However, due to its short half-life in the elimination phase, it had to be used for a longer period of time. Flurbiprofen is encapsulated in NLCs to evaluate the potential for intradermal delivery and diffusion into epidermal hair follicles [134].

The major drugs used in NLC delivery systems, along with their applications, are presented in Table 6.

Table 6. Drugs used in the NLC delivery system and their applications.

\begin{tabular}{|c|c|c|c|}
\hline Drug & Solid/Liquid Lipids & Use & Ref. \\
\hline \multicolumn{4}{|c|}{ Anticancer Drugs } \\
\hline $\begin{array}{l}\text { 5-fluorouracil and retinoic } \\
\text { acid conjugate }\end{array}$ & Lecithin/oleic acid & Large intestine cancer in people & [135] \\
\hline Oridonin & GMS/MCT & $\begin{array}{l}\text { Extension of mean lifetime of retention of oridonin } \\
\text { encapsulated in NLC coated with PEG }\end{array}$ & [136] \\
\hline Docetaxel & GMS/oleic acid & $\begin{array}{l}\text { In vivo studies have shown greater effectiveness in } \\
\text { treatment of malignant melanoma and weaker side effects }\end{array}$ & {$[137]$} \\
\hline Etoposide & GMS/soybean oil & $\begin{array}{l}\text { Etoposide in NLC was optimized formulation of } \\
\text { enhanced bioavailability in oral administration of the } \\
\text { system, showing high cytotoxicity towards } \\
\text { plano-epithelial cells of lung cancer }\end{array}$ & {$[138]$} \\
\hline Topotecan & Stearic acid/oleic acid & $\begin{array}{l}\text { Incorporation of topotecan to NLC improved its } \\
\text { properties, chemical stability and increased its cytotoxicity }\end{array}$ & [139] \\
\hline \multicolumn{4}{|c|}{ Anti-inflammatory drugs } \\
\hline Flurbiprofen & GMS/MCT & $\begin{array}{l}\text { Flurbiprofen encapsulated in NLC showed better } \\
\text { permeability on topical application and was more } \\
\text { effective than in oral administration }\end{array}$ & [119] \\
\hline Ketoprofen & $\begin{array}{l}\text { Compritol } 888 \\
\text { ATO/labrafac lipophile }\end{array}$ & $\begin{array}{l}\text { The new system of drug entrapped in cyclodextrin } \\
\text { (inclusion compound) and encapsulated in NLC } \\
\text { improved the therapeutic effectiveness of ketoprofen and } \\
\text { the safety of its use }\end{array}$ & [140] \\
\hline Quercetin & GMS/MCT & $\begin{array}{l}\text { Studies of penetration of quercetin through the skin } \\
\text { in vitro and in vivo proved that its encapsulation in NLC } \\
\text { increased its retention in the epidermis and thus } \\
\text { improved the therapeutic effect. }\end{array}$ & [141] \\
\hline
\end{tabular}


Table 6. Cont.

\begin{tabular}{|c|c|c|c|}
\hline Drug & Solid/Liquid Lipids & Use & Ref. \\
\hline \multicolumn{4}{|c|}{ Anti-inflammatory drugs } \\
\hline Celecoxib & Precirol/squalene & $\begin{array}{l}\text { Pharmacodynamic studies of celecoxib in NLC showed } \\
\text { extended to } 24 \text { h activity of the drug }\end{array}$ & [116] \\
\hline \multicolumn{4}{|c|}{ Antifungal drugs } \\
\hline Silybin & GMS/MCT & $\begin{array}{l}\text { The drug in GMS/MCT reached the blood circulation } \\
\text { system faster but was to a high degree captured by RES } \\
\text { (reticular endothelial system) in the organs (in particular } \\
\text { in the liver) }\end{array}$ & [142] \\
\hline Fluconazole & $\begin{array}{l}\text { Compritol } 888 \text { ATO } \\
\text { (CA)/oleic acid }\end{array}$ & $\begin{array}{l}\text { Encapsulation of the drug in NLC ensured effective and } \\
\text { extended release of the drug in the skin, which increased } \\
\text { effectiveness of fungal infection }\end{array}$ & [143] \\
\hline Itraconazole & $\begin{array}{c}\text { GMS, prekirol/oleic acid, } \\
\text { miglyol }\end{array}$ & $\begin{array}{l}\text { Itraconazole was encapsulated to stable NLC whose } \\
\text { properties were unaffected on introduction to the lungs }\end{array}$ & [144] \\
\hline \multicolumn{4}{|c|}{ Glucocorticoids } \\
\hline Dexamethasone & $\begin{array}{l}\text { GMS/medium chain } \\
\text { triacyclglycerols (MCT) }\end{array}$ & $\begin{array}{l}\text { Dexamethasone in a complex incorporated into NLC } \\
\text { showed high stability and extended release of active } \\
\text { ingredient }\end{array}$ & [145] \\
\hline Fluticasone & Precirol ATO 5 /labrasol & $\begin{array}{l}\text { The presence of PEG-containing lipids in NLC improved } \\
\text { the drug stability }\end{array}$ & [146] \\
\hline \multicolumn{4}{|c|}{ Corticosteroids } \\
\hline Triamcilone acetonide & Prekirol ATO 5 / squalene & $\begin{array}{l}\text { In vivo tests in mice proved increased stability of the drug } \\
\text { encapsulated in NLC and the possibility of its delivery to } \\
\text { the back part of the eye }\end{array}$ & [147] \\
\hline \multicolumn{4}{|c|}{ Antioxidants } \\
\hline Resveratrol & $\begin{array}{l}\text { Compritol } 888 \\
\text { ATO/miglyol }\end{array}$ & $\begin{array}{l}\text { Resveratrol encapsulated in NLC showed higher } \\
\text { antioxidation activity than the same drug incorporated in } \\
\text { SLN }\end{array}$ & [148] \\
\hline Curcumin & GMS/MCT & $\begin{array}{l}\text { The encapsulation of curcumin in an NLC resulted in an } \\
\text { increase in its antimalarial activity }\end{array}$ & [149] \\
\hline Lutein & Precirol ATO 5 & $\begin{array}{l}\text { NLC was shown to protect lutein against the simulated } \\
\text { gastric fluid and allowed its slow release in the simulated } \\
\text { intestinal fluid }\end{array}$ & [150] \\
\hline \multicolumn{4}{|c|}{ Immunosuppressants } \\
\hline Tacrolimus & GMS/oleic acid & $\begin{array}{l}\text { Tests in vitro revealed that encapsulation of tacrolimus in } \\
\text { NLC increases its penetration coefficient to a value of } 1.64 \\
\text { times greater than that of the commercial ointment with } \\
\text { tacrolimus Protopic }\end{array}$ & [151] \\
\hline \multicolumn{4}{|c|}{ Antipsoriatic drugs } \\
\hline Acitretin & Precirol ATO 5 / oleic acid & $\begin{array}{l}\text { The system Precirol ATO5/ oleic acid / NLC proved to be } \\
\text { effective in treatment of psoriasis }\end{array}$ & [152] \\
\hline Psoralen & Precirol/squalene & $\begin{array}{l}\text { The system Precirol/ squalene showed increased } \\
\text { penetration and possibility of controlled drug release }\end{array}$ & [117] \\
\hline Lidocaine & $\begin{array}{c}\text { Compritol } 888 \\
\text { ATO/miglyol } 810\end{array}$ & $\begin{array}{l}\text { Topical application of lidocaine encapsulated in NLC in } \\
\text { gel form permits slow development of local anesthesia in } \\
\text { guinea pigs }\end{array}$ & [153] \\
\hline \multicolumn{4}{|c|}{ Antimalarial drugs } \\
\hline Dihydroartemisinin & GMS/miglyol 812 & $\begin{array}{l}\text { The course of release of dihydroartemisinin incorporated } \\
\text { in NLC indicated the formation of diphase pattern in the } \\
\text { beginning phase and extended release later }\end{array}$ & [154] \\
\hline \multicolumn{4}{|c|}{ Sunscreens } \\
\hline Oxybenzone & GMS/miglyol & $\begin{array}{l}\text { Incorporation of oxybenzone to NLC has considerably } \\
\text { increased its sunscreen index }\end{array}$ & [155] \\
\hline
\end{tabular}




\section{Lipid Nanoparticles as Carriers of Viral Proteins}

The emergence of a previously unknown SARS-CoV-2 virus (COVID-19) in Hubei Province, China, in December 2019 shocked the world. The virus has spread rapidly, taking over the entire world [156,157]. The World Health Organization (WHO) declared it a public health emergency of international concern [158]. Scientists from all over the world have unanimously agreed that a vaccine against COVID-19 is the most effective way to combat the pandemic and protect human health. Consequently, researchers around the world pursued the development of a vaccine against this virus [159].

Thanks to the efforts of researchers and international collaborations, a number of potential vaccines capable of combating COVID-19 have been rapidly developed. We can divide them into the following:

- vector vaccines based on fragments of other viruses,

- mRNA vaccines;

- subunit vaccines, which contain purified viral proteins in their composition.

Vector-based vaccines are based on cold viruses, which are harmless to humans and are found in chimpanzees. These viruses, which are part of the adenovirus family, have been modified to contain the gene responsible for the production of the SARS-CoV-2 entry protein $[160,161]$. Research on mRNA-based vaccines has been conducted for a long time. Their main principle is to encode the antigen in mRNA and then deliver the transcript to the cytoplasm of the host cell using a non-viral delivery system that enables antigen expression and induction of an antigen-specific immune response [162]. Currently, there are three main types of RNA-based vaccines:

- conventional, non-amplifying base-modified messenger RNA (mRNA) molecules;

- non-amplifying mRNA (bmRNA) that contain chemically modified nucleotides;

- self-amplifying mRNAs (saRNAs or replicons) that retain auto replicative activity, extracted from a viral RNA vector [160,162].

The COVID-19 vaccine contains an mRNA molecule that contains the instructions for making the spike protein. This protein is found on the surface of the SARS-CoV-2 virus. The virus needs it in order to enter the body's cells. When a person is given a vaccine, some of their cells read the mRNA instructions and temporarily produce the "spike" protein. The vaccinated person's immune system recognizes this protein as foreign, produces antibodies, and activates $\mathrm{T}$ lymphocytes whose purpose is to fight the virus. If the vaccinated person later comes into contact with the SARS-CoV-2 virus, their immune system will recognize it and be ready to defend the body; the mRNA from the vaccine does not remain in the body but breaks down soon after vaccination [163].

Scientists are constantly investigating the possibility of efficiently and rapidly transferring the therapeutic substance into the human body; moreover, the question of whether lipid nanoparticles can be carriers of viruses was born. By using NLPs as mRNA carriers, it has become possible to effectively and safely control the SARS-CoV-2 virus. Efficient delivery of these vaccines requires that the mRNA has to be protected against extracellular degradation [164]. One of the first vaccines based on mRNA and lipid nanoparticles was Moderna's non-replicating mRNA vaccine, mRNA-1273 [165-167], while BioNTech/Pfizer's vaccine, BNT162b2, was the first to be circulated in the UK and then in Canada, with an impressive efficacy of 95\% [168]. The most important and effective vaccines developed based on RNA and lipid nanoparticles are summarized in Table 7 [162].

Nanoparticles and viruses operate on a similar size scale so that nanoparticles can enter cells to enable the expression of antigens from delivered nucleic acids (mRNA and DNA vaccines). Many vaccine technologies use such properties to encapsulate genomic material or protein/polypeptide (oligopeptide) antigens in lipid nanoparticles (LNP) [169]. Both BioNTech/Pfizer and Moderna use lipid nanoparticles as mRNA carriers in their vaccines (Table 8 ). 
Table 7. Summary of mRNA-based vaccines against the SARS-CoV-2 virus (modified from [162]; original paper under the terms of the Creative Commons CC BY-NC 3.0).

\begin{tabular}{lcc}
\hline \multicolumn{1}{c}{ Company } & Type of mRNA & Delivery System \\
\hline Moderna & bmRNA & LNP \\
\hline BioNTech/Pfizer & bmRNA & LNP \\
\hline ICL & saRNA & LNP \\
\hline Arcturus & saRNA & LNP \\
\hline CureVac & mRNA & LNP \\
\hline
\end{tabular}

Table 8. Comparison of BioNTech/Pfizer and Moderna vaccines based on mRNA and lipid nanoparticles.

\begin{tabular}{|c|c|c|}
\hline & BioNTech/Pfizer & Moderna \\
\hline $\begin{array}{l}\text { Name of the } \\
\text { medicinal product }\end{array}$ & $\begin{array}{c}\text { Comirnaty concentrate for dispersion for injection. } \\
\text { COVID-19 mRNA vaccine (with } \\
\text { modified nucleosides) }\end{array}$ & $\begin{array}{l}\text { COVID-19 Vaccine Moderna dispersion for } \\
\text { injection. COVID-19 mRNA vaccine (with } \\
\text { modified nucleosides) }\end{array}$ \\
\hline List of excipients & $\begin{array}{l}\text { lipids: } \\
\text { ((4-hydroxybutyl)azanediyl)bis(hexane-6,1- } \\
\text { diyl)bis(hexyl 2-decanoate), (ALC-0315) } \\
\text { 2-[(polyethylene } \\
\text { glycol)-2000]-N,N-ditetradecylacetamide, } \\
\text { (ALC-0159) } \\
\text { 1,2-distearoyl-sn-glycero-3-phosphocholine } \\
\text { (DSPC) } \\
\text { - } \quad \text { cholesterol } \\
\text { - } \quad \text { potassium chloride } \\
\text { - } \quad \text { potassium dihydrogen phosphate } \\
\text { - } \quad \text { disodium chloride } \\
\text { - } \quad \text { sucrose } \\
\text { - } \quad \text { water for injection }\end{array}$ & $\begin{array}{ll}\text { - } & \text { lipid SM-102 } \\
\text { - } & \text { cholesterol } \\
\text { - } & \text { 1,2-distearyl-sn-glycero-3-phosphocholine } \\
& \text { (DSPC) } \\
\text { - } & \text { 1,2-dimethyl-rac-glycero-3- } \\
& \text { methoxypolyethylene glycol, molecular } \\
& \text { weight } 2000 \text { (PEG2000 DMG) } \\
\text { - } \quad \text { trometamol } \\
\text { - } \quad \text { trometamol hydrochloride } \\
\text { - } \quad \text { acetic acid } \\
\text { - } \quad \text { sodium acetate trihydrate } \\
\text { - } \quad \text { sucrose } \\
\text { water for injection }\end{array}$ \\
\hline Ref. & [170] & [171] \\
\hline
\end{tabular}

\section{Summary}

This literature review describes the properties and applications of nanocarriers such as liposomes, niosomes, and lipid nanoparticles. Active substance carriers are required to be effective and safe. An important part of the treatment is the delivery of the active substance to a specific site in the body and its release for the desired time. Amongst the various types of drug nanocarriers, lipid nanoparticles have shown great promise in the efficient delivery of therapeutics by various routes of administration. The excipients used for the fabrication of lipid nanoparticles are biocompatible, biodegradable, non-irritating, and most of them are approved with GRAS status. The main task of lipid nanoparticles is to increase the bioavailability of the incorporated active ingredient, to control therapeutics release, and improve intracellular permeation and regulation of active compounds delivery to well-defined sites. In addition, these materials can act as effective carriers of anticancer compounds, the use of which will minimize the occurrence of treatment side effects. Accordingly, they can be used in COVID-19 therapy and prevention.

Author Contributions: E.M.: Conceptualization, Visualization, Writing-original draft; A.F.-G.: Conceptualization, Visualization, Writing-editing; I.N.: Supervision, Funding acquisition, Project administration, Writing - editing. All authors have read and agreed to the published version of the manuscript.

Funding: The work was carried out within the project "Advanced biocomposites for tomorrow's economy BIOG-NET" funded by Foundation for Polish Science from the European Regional Develop- 
ment Fund (POIR.04.04.00-00-1792/18-00, I.N., A.F.-G.). Additionally, it was supported by grant no. POWR.03.02.00-00-I020/17 co-financed by the European Union through the European Social Fund under the Operational Program Knowledge Education Development (E.M.).

Institutional Review Board Statement: Not applicable.

Informed Consent Statement: Not applicable.

Data Availability Statement: Not applicable.

Conflicts of Interest: The authors declare that they have no conflict of interest.

\section{References}

1. Duan, Y.; Dhar, A.; Patel, C.; Khimani, M.; Neogi, S.; Sharma, P.; Siva Kumar, N.; Vekariya, R.L. A brief review on solid lipid nanoparticles: Part and parcel of contemporary drug delivery systems. RSC Adv. 2020, 10, 26777-26791. [CrossRef]

2. Selvamuthukumar, S.; Velmurugan, R. Nanostructured Lipid Carriers: A potential drug carrier for cancer chemotherapy. Lipids Health Dis 2012, 11, 159. [CrossRef] [PubMed]

3. Kelsal, R.W.; Hamley, I.W.; Geoghegan, M. Nanotechnologie, 1st ed.; Wydawnictow naukowe PWN: PWN Warszawa, Poland, 2008; pp. 19-29.

4. Saha, R.N.; VasanthaKumar, S.; Bende, G.; Snehalatha, M. Nanoparticulate drug delivery systems for cancer chemotherapy. Mol. Membr. Biol. 2010, 27, 215-231. [CrossRef] [PubMed]

5. Zhang, L.; Gu, F.; Chan, J.; Wang, A.; Langer, R.S.; Farokhzad, O.C. Nanoparticles in Medicine: Therapeutic Applications and Developments. Clin. Pharmacol. Ther. 2007, 83, 761-769. [CrossRef]

6. Kargozar, S.; Mozafari, M. Nanotechnology and Nanomedicine: Start small, think big. Mater. Today Proc. 2018, 5, 15492-15500. [CrossRef]

7. Agrahari, P.A.J.R.A.; Bhatia, A.K.; Sexna, A.G.; Pant, G.; Singh, R.P.; Mishra, R.R.; Mishra, V.K. Advance Applications of Nanotechnology in Medicine. Int. J. Sci. Res. 2016, 7, 1284-1315.

8. Battaglia, L.; Gallarate, M. Lipid nanoparticles: State of the art, new preparation methods and challenges in drug delivery. Expert Opin. Drug Deliv. 2012, 9, 497-508. [CrossRef]

9. Schwarz, C. Solid lipid nanoparticles (SLN) for controlled drug delivery II. Drug incorporation and physicochemical characterization. J. Microencapsul. 1999, 16, 205-213. [CrossRef]

10. Müller, R.H.; Petersen, R.D.; Hommoss, A.; Pardeike, J. Nanostructured lipid carriers (NLC) in cosmetic dermal products. Adv. Drug Deliv. Rev. 2007, 59, 522-530. [CrossRef]

11. Montenegro, L. Nanocarriers for skin delivery of cosmetic antioxidants. J. Pharm. Pharmacogn. Res. 2014, $2,73-92$.

12. Akbarzadeh, A.; Rezaei-Sadabady, R.; Davaran, S.; Joo, S.W.; Zarghami, N.; Hanifehpour, Y.; Samiei, M.; Kouhi, M.; Nejati-Koshki, K. Liposome: Classification, preparation, and applications. Nanoscale Res. Lett. 2013, 8, 102. [CrossRef]

13. Puri, A.; Loomis, K.; Smith, B.; Lee, J.-H.; Yavlovich, A.; Heldman, E.; Blumenthal, R. Lipid-Based Nanoparticles as Pharmaceutical Drug Carriers: From Concepts to Clinic. Crit. Rev. Ther. Drug Carr. Syst. 2009, 26, 523-580. [CrossRef]

14. Leitgeb, M.; Knez, Ž.; Primožič, M. Sustainable technologies for liposome preparation. J. Supercrit. Fluids 2020, 165, 104984.

15. Liu, X.; Huang, G. Formation strategies, mechanism of intracellular delivery and potential clinical applications of pH-sensitive liposomes. Asian. J. Pharm. Sci. 2013, 8, 319-328. [CrossRef]

16. Amarnath, S.; Sharma, U.S. Liposomes in drug delivery: Progress and limitations. Int. J. Pharm. 1997, 154, 123-140.

17. Shaheen, S.M.; Shakil, A.F.M.; Hossen, M.N.; Ahmed, M.; Amran, M.S.; Ul-Islam, M.A. Liposome as a carrier for advanced drug delivery. Pak. J. Biol. Sci. 2006, 9, 1181-1191. [CrossRef]

18. Rafe, M.R.; Ahmed, Z. Liposomal Drug Delivery Systems Have Opened a New Window in Pharmaceutical Sciences: A Literaturebased Review. Asian J. Pharm. 2017, 11, 250-254.

19. Seema, R.; Chanchal, C.; Ravi, S.; Ankur, R.; Dinesh, K.; Satish, S.; Harish, D. Liposomes: Preparations and applications. Int. J. Drug. Dev. Res. 2012, 4, 108-115.

20. Bulbake, U.; Doppalapudi, S.; Kommineni, N.; Khan, W. Liposomal Formulations in Clinical Use: An Updated Review. Pharmaceutics 2017, 9, 12. [CrossRef]

21. Lamichhane, N.; Udayakumar, T.S.; D'Souza, W.D.; Simone, C.B.; Raghavan, S.R.; Polf, J.; Mahmood, J. Liposomes: Clinical Applications and Potential for Image-Guided Drug Delivery. Molecules 2018, 23, 288. [CrossRef]

22. Kataria, S.; Sandhu, P.; Bilandi, A.; Akanksha, M.; Kapoor, B.; Seth, G.L.; Bihani, S.D. Stealth liposomes: A review. IJRAP 2011, 2, 1534-1538.

23. Riaz, M. Liposomes preparation methods. Pak. J. Pharm. Sci. 1996, 9, 65-77.

24. Available online: https://www.pharmaceuticalonline.com/doc/an-introduction-to-liposome-processing-for-drug-delivery-0001 (accessed on 10 June 2020).

25. Himanshu, A.; Sitasharan, P.; Singhai, A.K. Liposomes as drug carriers. IJPLS 2011, 2, 945-951.

26. Szoka, F., Jr.; Papahadjopoulos, D. Procedure for preparation of liposomes with large internal aqueous space and high capture by reverse-phase evaporation. Proc. Natl. Acad. Sci. USA 1978, 75, 4194-4198. [CrossRef] 
27. Çağdas, M.; Sezer, A.D.; Bucak, S. Liposomes as Potential Drug Carrier Systems for Drug Delivery, Application of Nanotechnology in Drug Delivery; Sezer, A.D., Ed.; IntechOpen: London, UK, 2014.

28. Knop, K.; Hoogenboom, R.; Fischer, D.; Schubert, U.S. Poly(ethylene glycol) in Drug Delivery: Pros and Cons as Well as Potential Alternatives. Angew. Chem. Int. Ed. 2010, 49, 6288-6308. [CrossRef]

29. Naseri, N.; Valizadeh, H.; Zakeri-Milani, P. Solid Lipid Nanoparticles and Nanostructured Lipid Carriers: Structure, Preparation and Application. Adv. Pharm. Bull. 2015, 5, 305-313. [CrossRef]

30. Skólmowska, M.; Kmieć, M. Enzymosomy antyoksydacyjne-Właściwości i zastosowanie. Postępy Hig. Med. Dośw. 2011, 65, 640-644.

31. Jarząb, A.; Skowicki, M.; Witkowska, D. Szczepionki podjednostkowe—antygeny, nośniki, metody koniugacji rola adiuwantów. Postępy Hig. Med. Dośw. 2013, 67, 1128-1143. [CrossRef]

32. Miller, C.R.; Bondurant, B.; McLean, S.D.; McGovern, K.A.; O’Brien, D.F. Liposome-Cell Interactions in Vitro: Effect of Liposome Surface Charge on the Binding and Endocytosis of Conventional and Sterically Stabilized Liposomes. Biochemistry 1998, 37, 12875-12883. [CrossRef]

33. Durak, S.; Rad, M.E.; Yetisgin, A.A.; Sutova, H.E.; Kutlu, O.; Cetinel, S.; Zarrabi, A. Niosomal Drug Delivery Systems for Ocular Disease-Recent Advances and Future Prospects. Nanomaterials 2020, 10, 1191. [CrossRef] [PubMed]

34. Arunothayanun, P.; Bernard, M.S.; Craig, D.Q.M.; Uchegbu, I.F.; Florence, A.T. The effect of processing variables on the physical characteristics of non-ionic surfactant vesicles (niosomes) formed from a hexadecyl diglycerol ether. Int. J. Pharm. 2000, 201, 7-14. [CrossRef]

35. Paolino, D.; Cosco, D.; Muzzalupo, R.; Trapasso, E.; Picci, N.; Fresta, M. Innovative bola-surfactant niosomes as topical delivery systems of 5-fluorouracil for the treatment of skin cancer. Int. J. Pharm. 2008, 353, 233-242. [CrossRef] [PubMed]

36. Paolino, D.; Muzzalupo, R.; Ricciardi, A.; Celia, C.; Picci, N.; Fresta, M. In vitro and in vivo evaluation of Bola-surfactant containing niosomes for transdermal delivery. Biomed. Microdev. 2007, 9, 421-433. [CrossRef] [PubMed]

37. Yoshioka, T.; Sternberg, B.; Florence, A.T. Preparation and properties of vesicles (niosomes) of sorbitan monoesters (Span 20, 40, 60 and 80) and a sorbitan triester (Span 85). Int. J. Pharm. 1994, 105, 1-6. [CrossRef]

38. Okore, V.C.; Attama, A.A.; Ofokansi, K.C.; Esimone, C.O.; Onuigbo, E.B. Formulation and Evaluation of Niosomes. Ind. J. Pharm. Sci. 2011, 73, 323-328. [CrossRef]

39. Akhilesh, D.; Bini, K.B.; Kamath, J.V. Review on span-60 based non-ionic surfactant vesicles (niosomes) as novel drug delivery. Int. J. Res. Pharm. Biomed. Sci. 2012, 3, 6-12.

40. Jain, C.P.; Vyas, S.P. Preparation and characterization of niosomes containing rifampicin for lung targeting. J. Microencapsul. 1995, 12, 401-407. [CrossRef]

41. Marianecci, C.; Rinaldi, F.; Mastriota, M.; Pieretti, S.; Trapasso, E.; Paolino, D.; Carafa, M. Anti-inflammatory activity of novel ammonium glycyrrhizinate/niosomes delivery system: Human and murine models. J. Control Release 2012, 164, 17-25. [CrossRef]

42. Mandal, S.; Banerjee, C.; Ghosh, S.; Kuchlyan, J.; Sarkar, N. Modulation of the Photophysical Properties of Curcumin in Nonionic Surfactant (Tween-20) Forming Micelles and Niosomes: A Comparative Study of Different Microenvironments. J. Phys. Chem. B 2013, 117, 6957-6968. [CrossRef]

43. Marzio, L.D.; Marianecci, C.; Petrone, M.; Rinaldi, F.; Carafa, M. Novel pH-sensitive non-ionic surfactant vesicles: Comparison between Tween 21 and Tween 20. Colloids Surf. B Biointerfaces 2011, 82, 18-24. [CrossRef]

44. Bandyopadhyay, P.; Johnson, M. Fatty alcohols or fatty acids as niosomal hybrid carrier: Effect on vesicle size, encapsulation efficiency and in vitro dye release. Colloids Surf. B Biointerfaces 2007, 58, 68-71. [CrossRef]

45. Tavano, L.; Muzzalupo, R.; Mauro, L.; Pellegrino, M.; Andò, S.; Picci, N. Transferrin-Conjugated Pluronic Niosomes as a New Drug Delivery System for Anticancer Therapy. Langmuir 2013, 29, 12638-12646. [CrossRef]

46. Muzzalupo, R.; Tavano, L.; Cassano, R.; Trombino, S.; Ferrarelli, T.; Picci, N. A new approach for the evaluation of niosomes as effective transdermal drug delivery systems. Eur. J. Pharm. Biopharm. 2011, 79, 28-35. [CrossRef]

47. Bragagni, M.; Mennini, N.; Furlanetto, S.; Orlandini, S.; Ghelardini, C.; Mura, P. Development and characterization of functionalized niosomes for brain targeting of dynorphin-B. Eur. J. Pharm. Biopharm. 2014, 87, 73-79. [CrossRef]

48. Sankhyan, A.; Pawar, P. Recent trends in niosome as vesicular drug delivery system. J. Appl. Pharm. Sci. 2012, 2, 20-32.

49. Junyaprasert, V.B.; Teeranachaideekul, V.; Supaperm, T. Effect of Charged and Non-ionic Membrane Additives on Physicochemical Properties and Stability of Niosomes. AAPS Pharm. Sci. Tech. 2008, 9, 851-859. [CrossRef]

50. Gharbavi, M.; Amani, J.; Kheiri-Manjili, H.; Danafar, H.; Sharafi, A. Niosome: A Promising Nanocarrier for Natural Drug Delivery through Blood-Brain Barrier. Adv. Pharmacol. Sci. 2018, 2018, 1-15. [CrossRef]

51. Amoabediny, G.; Haghiralsadat, F.; Naderinezhad, S.; Helder, M.N.; Akhoundi Kharanaghi, E.; Mohammadnejad Arough, J.; Zandieh-Doulabi, B. Overview of preparation methods of polymeric and lipid-based (niosome, solid lipid, liposome) nanoparticles: A comprehensive review. Int. J. Polym. Mater. Polym. Biomater. 2018, 67, 383-400. [CrossRef]

52. Rinaldi, F.; Del Favero, E.; Moeller, J.; Hanieh, P.N.; Passeri, D.; Rossi, M.; Angeloni, L.; Venditti, I.; Marianecci, C.; Carafa, M.; et al. Hydrophilic Silver Nanoparticles Loaded into Niosomes: Physical-Chemical Characterization in View of Biological Applications. Nanomaterials 2019, 9, 1177. [CrossRef]

53. Haran, G.; Coben, R.; Bar, L.K.; Barenholz, Y. Vesicular drug delivery system-an overview. Biophys. Acta 1993, 1151, 201. [CrossRef]

54. Rahman, H.S.; Othman, H.H.; Hammadi, N.I.; Yeap, S.K.; Amin, K.M.; Abdul Samad, N.; Alitheen, N.B. Novel Drug Delivery Systems for Loading of Natural Plant Extracts and Their Biomedical Applications. Int. J. Nanomed. 2020, 15, 2439-2483. [CrossRef] 
55. Ramadan, A.A.; ElAdawy, S.A.; Abu El-Enin, A.S.M.; Hussein, Z.M. Development and investigation of timolol maleate niosomal formulations for the treatment of glaucoma. J. Pharm. Investig. 2020, 50, 59-70. [CrossRef]

56. Moghassemi, S.; Hadjizadeh, A.J. Nano-niosomes as nanoscale drug delivery systems: An illustrated review. J. Control Release 2014, 185, 22-36. [CrossRef]

57. More, V.V.; Gilhotra, R.M.; Nitalikar, M.M.; Khule, P.K. Niosomal Drug Delivery-A Comprehensive Review. Asian J. Pharm. 2019, $12,1159-1164$.

58. Talsma, H.; Van Steenbergen, M.J.; Borchert, J.C.; Crommelin, D.J. A Novel Technique for the One-Step Preparation of Liposomes and Nonionic Surfactant Vesicles without the Use of Organic Solvents. Liposome Formation in a Continuous Gas Stream: The 'Bubble' Method. J. Pharm. Sci. 1994, 83, 276-280. [CrossRef]

59. Abdelkader, H.; Ismail, S.; Kamal, A.; Alany, R.G. Design and Evaluation of Controlled-Release Niosomes and Discomes for Naltrexone Hydrochloride Ocular Delivery. J. Pharm. Sci. 2011, 100, 1833-1846. [CrossRef]

60. Manosroi, A.; Chutoprapat, R.; Abe, M.; Manosroi, J. Characteristics of niosomes prepared by supercritical carbon dioxide (scCO2) fluid. Int. J. Pharm. 2008, 352, 248-255. [CrossRef]

61. Begum, K.; Khan, A.F.; Hana, H.K.; Sheak, J.; Jalil, R.U. Rifampicin Niosome: Preparations, Characterizations and Antibacterial Activity Against Staphylococcus aureus and Staphylococcus epidermidis Isolated from Acne. Dhaka Univ. J. Pharm. Sci. 2015, 14, 117-123. [CrossRef]

62. Seleci, D.A.; Seleci, M.; Walter, J.-G.; Stahl, F.; Scheper, T. Niosomes as Nanoparticular Drug Carriers: Fundamentals and Recent Applications. J. Nanomater. 2016, 2016, 1-13. [CrossRef]

63. Muller, H.R.; Shegokar, R.; Keck, C.M. 20 Years of Lipid Nanoparticles (SLN \& NLC): Present State of Development \& Industrial Applications. Curr. Drug Discov. Technol. 2011, 8, 207-227. [CrossRef]

64. Shah, M. Solid Lipid Nanoparticles (SLN) for Oral Drug Delivery: An Overview. J. Nanomed. Nanosci. 2017, 2, 1-2.

65. Ekambaram, P.; Sathali, A.A.H.; Priyanka, K. Solid lipid nanoparticles: A review. Sci. Rev. Chem. Commun. 2012, $2,80-102$.

66. Pardeike, J.; Hommoss, A.; Müller, R.H. Lipid nanoparticles (SLN, NLC) in cosmetic and pharmaceutical dermal products. Int. J. Pharm. 2009, 366, 170-184. [CrossRef] [PubMed]

67. Banerjee, S.; Pillai, J. Solid lipid matrix mediated nanoarchitectonics for improved oral bioavailability of drugs. Expert Opin Drug Metab Toxicol. 2019, 15, 499-515. [CrossRef]

68. Weyhers, H.; Ehlers, S.; Hahn, H.; Souto, E.B.; Müller, R.H. Solid lipid nanoparticles (SLN)—Effects of lipid composition on in vitro degradation and in vivo toxicity. Die Pharm. 2006, 61, 539.

69. Rupesh, K.; Shirodkar, L.K.; Srinivas, M.; Shaila, L. Solid Lipid Nanoparticles and Nanostructured Lipid Carriers: Emerging Lipid Based Drug Delivery Systems. Pharm. Chem. J. 2019, 53, 440-453.

70. Múller, R.H.; Mehnert, W.; Lucks, J.S.; Schwarz, C.; Zur Múehlen, A.; Weyhers, H. Solid lipid nanoparticles (SLN)—An alternative colloidal carrier system for controlled drug delivery. Eur. J. Pharm. Biopharm. 1995, 41, 62-69.

71. Lasoń, E.; Ogonowski, J. Stałe Nanoczastki Lipidowe-Charakterystyka, zastosowanie i otrzymywanie. Chemik 2011, 65, 960-967.

72. Wissing, S.A.; Kayser, O.; Müller, R.H. Solid lipid nanoparticles for parenteral drug delivery. Adv. Drug Deliv. Rev. 2004, 56, 1257-1272. [CrossRef]

73. Jenning, V.; Gohla, S. Encapsulation of retinoids in solid lipid nanoparticles (SLN). J. Microencapsul. 2001, 18, 149-158.

74. Müller, R.H.; Radtke, M.; Wissing, S.A. Nanostructured lipid matrices for improved microencapsulation of drugs. Int. J. Pharm. 2002, 242, 121-128. [CrossRef]

75. Müller, R.H.; Radtke, M.; Wissing, S.A. Nanostructured lipid carriers (NLC), the next generation after solid lipid nanoparticles (SLN). In Proceedings of the 4th World Meeting ADRITELF/APGI/APV, Florence, Italy, 8-11 April 2002; pp. 673-674.

76. Teixeira, M.C.; Carbone, C.; Souto, E.B. Beyond liposomes: Recent advances on lipid based nanostructures for poorly soluble/poorly permeable drug delivery. Prog. Lipid Res. 2017, 68, 1-11. [CrossRef]

77. Carbone, C.; Martins-Gomes, C.A.; Caddeo, C.; Silva, A.M.; Musumeci, T.; Pignatello, R.; Puglisi, G.; Souto, E.B. Mediterranean essential oils as precious matrix components and active ingredients of lipid nanoparticles. Int. J. Pharm. 2018, 548, 217-226. [CrossRef]

78. Moral, S.P.; Teixeira, M.C.; Fernandes, A.R.; Linares, I.B.; Román, D.A.; Férez, A.M.; Carretero, A.S.; Souto, E.B. Polyphenolsenriched Hibiscus sabdariffa extract-loaded nanostructured lipid carriers (NLC): Optimization by multi-response surface methodology. J. Drug Deliv. Sci. Technol. 2019, 49, 660-667. [CrossRef]

79. Radtke, M.; Souto, E.B.; Müller, R.H. Nanostructured lipid carriers: A novel generation of solid lipid drug carriers. Pharm. Technol. Eur. 2005, 17, 45-50.

80. Ganesan, P.; Narayanasamy, D. Lipid nanoparticles: Different preparation techniques, characterization, hurdles, and strategies for the production of solid lipid nanoparticles and nanostructured lipid carriers for oral drug delivery. Sustain. Chem. Pharm. 2017, 6, 37-56. [CrossRef]

81. Kasongo, K.W.; Müller, R.H.; Walker, R.B. The use of hot and cold high pressure homogenization to enhance the loading capacity and encapsulation efficiency of nanostructured lipid carriers for the hydrophilic antiretroviral drug, didanosine for potential administration to paediatric patients. Pharm. Dev. Technol. 2012, 17, 353-362. [CrossRef]

82. Gasco, M.R. Method for Producing Solid Lipid Microspheres Having a Narrow Size Distribution. U.S. Patent US5250236A, 5 October 1993. 
83. Beloqui, A.; Solinís, M.A.; Gascón, A.R.; Almeida, A.J.; Préat, V. Nanostructured lipid carriers: Promising drug delivery systems for future clinics. Nanomed. Nanotechnol. Biol. Med. 2016, 12, 143-161. [CrossRef]

84. Lippacher, A.; Müller, R.H.; Mäder, K. Investigation on the viscoelastic properties of lipid based colloidal drug carriers. Int. J. Pharm. 2000, 196, 227-230. [CrossRef]

85. Mehnert, W.; Mäder, K. Solid lipid nanoparticles production, characterization and applications. Adv. Drug Deliv. Rev. 2001, 47, 165-196. [CrossRef]

86. Müller, R.H.; Radtke, M.; Wissing, S.A. Solid lipid nanoparticles (SLN) and nanostructured lipid carriers (NLC) in cosmetic and dermatological preparations. Adv. Drug Deliv. Rev. 2002, 54, S131-S155. [CrossRef]

87. Müller, R.H.; Mäder, K.; Gohla, S. Solid lipid nanoparticles (SLN) for controlled drug delivery-A review of the state of the art. Eur. J. Pharm. Biopharm. 2000, 50, 161-177. [CrossRef]

88. Souto, E.B.; Baldmin, I.; Oliveira, W.P.; Rao, R.; Yadav, N.; Francisco, M.G.; Mahant, S. SLN and NLC for topical, dermal, and transdermal drug delivery. Expert Opin. Drug Deliv. 2020, 17, 357-377. [CrossRef] [PubMed]

89. Rodriguez, A.D.P.; Delgado, D.; Gascon, A.R.; Solinis, M.A. Lipid nanoparticles as drug/gene delivery systems to the retina. J. Ocul. Pharmacol. Ther. 2013, 29, 173-188. [CrossRef]

90. Muchow, M.; Maincent, P.; Müller, R.H. Lipid Nanoparticles with a Solid Matrix $\left(\mathrm{SLN}^{\circledR}{ }^{\circledR}, \mathrm{NLC}^{\circledR}\right.$, LDC $\left.^{\circledR}\right)$ for Oral Drug Delivery. Drug Dev. Ind. Pharm. 2008, 34, 1394-1405. [CrossRef]

91. Sjörström, B.; Bergenståhl, B. Preparation of submicron drug particles in lecithin-stabilized o/w emulsions. I. Model studies of the precipitation of cholesteryl acetate. Int. J. Pharm. 1992, 88, 53-62. [CrossRef]

92. Trotta, M.; Debernardi, F.; Caputo, O. Preparation of solid lipid nanoparticles by a solvent emulsification-diffusion technique. Int J. Pharm. 2003, 257, 153-160. [CrossRef]

93. Guerrero, D.Q.; Esquivel, D.T.; Quintanar, A.G.; Allémann, E.; Doelker, E. Adaptation and optimization of the emulsificationdiffusion technique to prepare lipidic nanospheres. Eur. J. Pharm. Sci. 2005, 262, 211-218. [CrossRef]

94. Liu, D.; Jiang, S.; Shen, H.; Qin, S.; Liu, J.; Zhang, Q.; Li, R.; Xu, Q. Diclofenac sodium-loaded solid lipid nanoparticles prepared by emulsion/solvent evaporation method. J. Nanopart. Res. 2011, 13, 2375-2386. [CrossRef]

95. Das, S.; Chaudhury, A. Recent Advances in Lipid Nanoparticle Formulations with Solid Matrix for Oral Drug Delivery. AAPS Pharm. Sci. Tech. 2010, 12, 62-76. [CrossRef]

96. Liu, K.; Sun, J.; Wang, Y.; He, Y.; Gao, K.; He, Z. Preparation and Characterization of 10-Hydroxycamptothecin Loaded Nanostructured Lipid Carriers. Drug Dev. Ind. Pharm. 2008, 34, 465-471. [CrossRef]

97. Schubert, M.; Goymann, C.C.M. Solvent injection as a new approach for manufacturing lipid nanoparticles-Evaluation of the method and process parameters. Eur. J. Pharm. Biopharm. 2003, 55, 125-131. [CrossRef]

98. Charcosset, C.; El-Herati, A.; Fessi, H. Preparation of solid lipid nanoparticles using a membrane contactor. J. Control Release 2005, 108, 112-120. [CrossRef]

99. Li, Y.; Fessi, H.; Charcosset, C. Preparation of Indomethacin-Loaded Lipid Particles by Membrane Emulsification. Adv. Sci. Lett. 2011, 4, 591-595. [CrossRef]

100. Wang, M.; Thanou, M. Thargeting nanoparticles to cancer. Pharmacol. Res. 2010, 62, 90-99. [CrossRef]

101. Tagami, T.; Ozeki, T. Recent Trends in Clinical Trials Related to Carrier-Based Drugs. J. Pharm. Sci. 2017, 106, 2219-2226. [CrossRef]

102. Yang, S.C.; Lu, L.F.; Cai, Y.; Zhu, J.B.; Liang, B.W.; Yang, C.Z. Body distribution in mice of intravenously injected camptothecin solid lipid nanoparticles and targeting effect on brain. J. Control Release 1999, 59, 299-307. [CrossRef]

103. Pandey, R.; Sharma, S.; Khuller, G.K. Oral solid lipid nanoparticle-based antitubercular chemotherapy. Tuberculosis 2005, 85, 415-420. [CrossRef]

104. Sznitowska, M.; Gajewska, M.; Janicki, S.; Radwanska, A.; Lukowski, G. Bioavailability of diazepam from aqueous-organic solution, submicron emulsion and solid lipid nanoparticles after rectal administration in rabbits. Eur. J. Pharm. Biopharm. 2001, 52, 159-163. [CrossRef]

105. Friedrich, I.; Reichl, S.; Goymann, C.C.M. Drug release and permeation studies of nanosuspensions based on solidified reverse micellar solutions (SRMS). Int. J. Pharm. 2005, 305, 167-175. [CrossRef]

106. Almeida, A.J.; Souto, E. Solid lipid nanoparticles as a drug delivery system for peptides and proteins. Adv. Drug Deliv. Rev. 2007, 59, 478-490. [CrossRef]

107. Fundarò, A.; Cavalli, R.; Bargoni, A.; Vighetto, D.; Zara, G.P.; Gasco, M.R. Non-stealth and stealth solid lipid nanoparticles (SLN) carrying doxorubicin: Pharmacokinetics and tissue distribution after i.v. administration to rats. Pharmacol. Res. 2000, 42, 337-343. [CrossRef]

108. Zara, G.P.; Cavalli, R.; Bargoni, A.; Fundarò, A.; Vighetto, D.; Gasco, M.R. Intravenous Administration to Rabbits of Non-stealth and Stealth Doxorubicin-loaded Solid Lipid Nanoparticles at Increasing Concentrations of Stealth Agent: Pharmacokinetics and Distribution of Doxorubicin in Brain and Other Tissues. J. Drug Target. 2002, 10, 327-335. [CrossRef]

109. Cavalli, R.; Zara, G.P.; Caputo, O.; Bargoni, A.; Fundarò, A.; Gasco, M.R. Transmucosal transport of tobramycin incorporated in solid lipid nanoparticles (SLN) after duodenal administration, Part I-A pharmacokinetic study. Pharmacol. Res. 2000, 42, 541-545. [CrossRef]

110. Bargoni, A.; Cavalli, R.; Zara, G.P.; Fundarò, A.; Caputo, O.; Gasco, M.R. Transmucosal transport of tobramycin incorporated in solid lipid nanoparticles (SLN) after duodenal administration, Part II-Tissue distribution. Pharmacol. Res. 2001, 43, 497-502. [CrossRef] 
111. Begley, D.J. Delivery of therapeutic agents to the central nervous system: The problems and the possibilities. Pharmacol. Ther. 2004, 104, 29-45. [CrossRef]

112. Eyal, S.; Hsiao, P.; Unadkat, J.D. Drug interactions at the blood-brain barrier: Fact or fantasy? Pharmacol. Ther. 2009, 123, 80-104 [CrossRef]

113. Wiątkiewicz, K.B.; Olszewska, P.; Olasik, E.M. Zastosowanie nanocząsteczek w leczeniu i diagnostyce nowotworów. Nowotw. J. Oncol. 2013, 63, 320-330.

114. Cho, K.J.; Wang, X.; Nie, S.; Chen, Z.; Shin, D.M. Therapeutic Nanoparticles for Drug Delivery in Cancer. Clin. Cancer Res. 2008, 14, 1310-1316. [CrossRef]

115. Parveen, S.; Sahoo, S.K. Polymeric nanoparticles for cancer therapy. J. Drug Target. 2008, 16, 108-123. [CrossRef] [PubMed]

116. Joshi, M.; Patravale, V. Nanostructured lipid carrier (NLC) based gel of celecoxib. Int. J. Pharm. 2008, 346, 124-132. [CrossRef] [PubMed]

117. Fang, J.-Y.; Fang, C.-L.; Liu, C.-H.; Su, Y.-H. Lipid nanoparticles as vehicles for topical psoralen delivery: Solid lipid nanoparticles (SLN) versus nanostructured lipid carriers (NLC). Eur. J. Pharm. Biopharm. 2008, 70, 633-640. [CrossRef] [PubMed]

118. Zhao, J.; Piao, X.; Shi, X.; Si, A.; Zhang, Y.; Feng, N. Podophyllotoxin-loaded nanostructured lipid carriers for skin targeting: In vitro and in vivo studies. Molecules 2016, 21, 1549. [CrossRef] [PubMed]

119. Han, F.; Yin, R.; Che, X.; Yuan, J.; Cui, Y.; Yin, H.; Li, S. Nanostructured lipid carriers (NLC) based topical gel of flurbiprofen: Design, characterization and in vivo evaluation. Int. J. Pharm. 2012, 439, 349-357. [CrossRef]

120. Ricci, M.; Puglia, C.; Bonina, F.; Di Giovanni, C.; Giovagnoli, S.; Rossi, C. Evaluation of Indomethacin Percutaneous Absorption from Nanostructured Lipid Carriers (NLC): In Vitro and In Vivo Studies. J. Pharm. Sci. 2005, 94, 1149-1159. [CrossRef]

121. Tronino, D.; Offerta, A.; Ostacolo, C.; Russo, R.; De Caro, C.; Calignano, A.; Puglia, C.; Blasi, P. Nanoparticles prolong Npalmitoylethanolamide anti-inflammatory and analgesic effects in vivo. Colloids Surf. B Biointerfaces 2016, 141, 311-317. [CrossRef]

122. Lin, C.-H.; Chen, C.-H.; Lin, Z.-C.; Fang, J.-Y. Recent advances in oral delivery of drugs and bioactive natural products using solid lipid nanoparticles as the carriers. J. Food Drug Anal. 2017, 25, 219-234. [CrossRef]

123. Desai, P.P.; Date, A.A.; Patravale, V.B. Overcoming poor oral bioavailability using nanoparticle formulations-Opportunities and limitations. Drug Discov. Today Technol. 2012, 9, e87-e95. [CrossRef]

124. Zhou, X.; Zhang, X.; Ye, Y.; Zhang, T.; Wang, H.; Ma, Z.; Wu, B. Nanostructured lipid carriers used for oral delivery of oridonin: An effect of ligand modification on absorption. Int. J. Pharm. 2015, 479, 391-398. [CrossRef]

125. Weber, S.; Zimmer, A.; Pardeike, J. Solid Lipid Nanoparticles (SLN) and Nanostructured Lipid Carriers (NLC) for pulmonary application: A review of the state of the art. Eur. J. Pharm. Biopharm. 2014, 86, 7-22. [CrossRef]

126. Paranjpe, M.; Goymann, C.C.M. Nanoparticle-mediated pulmonary drug delivery: A review. Int. J. Mol. Sci. 2014, 15, 5852-5873. [CrossRef]

127. Mansour, H.M.; Rhee, Y.S.; Wu, X. Nanomedicine in pulmonary delivery. Int. J. Nanomed. 2009, 4, 299-319. [CrossRef]

128. Labiris, N.R.; Dolovich, M.B. Pulmonary drug delivery. Part I: Physiological factors affecting therapeutic effectiveness of aerosolized medications. Br. J. Clin. Pharmacol. 2003, 56, 588-599. [CrossRef]

129. Gaudana, R.; Ananthula, H.K.; Parenky, A.; Mitra, A.K. Ocular drug delivery. AAPS J. 2010, 12, 348-360. [CrossRef]

130. Patel, A.; Cholkar, K.; Agrahari, V.; Mitra, A.K. Ocular drug delivery systems: An overview. World J. Pharmacol. 2013, 2, 47-64. [CrossRef]

131. Ghasemiyeh, P.; Samani, S.M. Solid lipid nanoparticles and nanostructured lipid carriers as novel drug delivery systems: Applications, advantages and disadvantages. Res. Pharm. Sci. 2018, 13, 288-303.

132. Gao, H. Progress and perspectives on targeting nanoparticles for brain drug delivery. Acta Pharm. Sin. B 2016, 6, 268-286. [CrossRef]

133. Garg, N.K.; Singh, B.; Tyagi, R.K.; Sharma, G.; Katare, O.P. Effective transdermal delivery of methotrexate through nanostructured lipid carriers in an experimentally induced arthritis model. Colloids Surf. B Biointerfaces 2016, 147, 17-24. [CrossRef]

134. Kawadkar, J.; Pathak, A.; Kishore, R.; Chauhan, M.K. Formulation, characterization and in vitro-in vivo evaluation of flurbiprofenloaded nanostructured lipid carriers for transdermal delivery. Drug Dev. Ind. Pharm. 2012, 39, 569-578. [CrossRef]

135. Varshosaz, J.; Hassanzadeh, F.; Sadeghi, H.M.-M.; Andalib, S. Synthesis of octadecylamine-retinoic acid conjugate for enhanced cytotoxic effects of 5-FU using LDL targeted nanostructured lipid carriers. Eur. J. Med. Chem. 2012, 54, 429-438. [CrossRef]

136. Jia, L.; Zhang, D.; Li, Z.; Duan, C.; Wang, Y.; Feng, F.; Wang, F.; Liu, Y.; Zhang, Q. Nanostructured lipid carriers for parenteral delivery of silybin: Biodistribution and pharmacokinetic studies. Colloids Surf. B Biointerfaces 2010, 80, 213-218. [CrossRef] [PubMed]

137. Liu, D.; Liu, Z.; Wang, L.; Zhang, C.; Zhang, N. Nanostructured lipid carriers as novel carrier for parenteral delivery of docetaxel Colloids Surf. B Biointerfaces 2011, 85, 262-269. [CrossRef] [PubMed]

138. Zhang, T.; Chen, J.; Zhang, Y.; Shen, Q.; Pan, W. Characterization and evaluation of nanostructured lipid carrier as a vehicle for oral delivery of etoposide. Eur. J. Pharm. Sci. 2011, 43, 174-179. [CrossRef] [PubMed]

139. Souza, L.G.; Silva, E.J.; Martins, A.L.L.; Mota, M.F.; Braga, R.; Lima, E.M.; Valadares, M.C.; Taveira, S.; Marreto, R.N. Development of topotecan loaded lipid nanoparticles for chemical stabilization and prolonged release. Eur. J. Pharm. Biopharm. 2011, 79, 189-196. [CrossRef] [PubMed]

140. Cirri, M.; Bragagni, M.; Mennini, N.; Mura, P. Development of a new delivery system consisting in "drug—In cyclodextrin—In nanostructured lipid carriers" for ketoprofen topical delivery. Eur. J. Pharm. Biopharm. 2012, 80, 46-53. [CrossRef] [PubMed] 
141. Chen-Yu, G.; Chun-Fen, Y.; Qi-Lu, L.; Qi, T.; Yan-Wei, X.; Wei-Na, L.; Guang-Xi, Z. Development of a Quercetin-loaded nanostructured lipid carrier formulation for topical delivery. Int. J. Pharm. 2012, 430, 292-298. [CrossRef]

142. Schäfer-Korting, M.; Mehnert, W.; Korting, H.-C. Lipid nanoparticles for improved topical application of drugs for skin diseases. Adv. Drug Deliv. Rev. 2007, 59, 427-443. [CrossRef]

143. Gupta, M.; Vyas, S.P. Development, characterization and in vivo assessment of effective lipidic nanoparticles for dermal delivery of fluconazole against cutaneous candidiasis. Chem. Phys. Lipids 2012, 165, 454-461. [CrossRef]

144. Pardeike, J.; Weber, S.; Haber, T.; Wagner, J.; Zarfl, H.P.; Plank, H.; Zimmer, A. Development of an Itraconazole-loaded nanostructured lipid carrier (NLC) formulation for pulmonary application. Int. J. Pharm. 2011, 419, 329-338. [CrossRef]

145. Zhao, C.; Liu, Y.; Fan, T.; Zhou, D.; Yang, Y.; Jin, Y.; Zhang, Z.; Huang, Y. A novel strategy for encapsulating poorly soluble drug into nanostructured lipid carriers for intravenous administration. Pharm. Dev. Technol. 2012, 17, 443-456. [CrossRef]

146. Doktorovová, S.; Araújo, J.; Garcia, M.L.; Rakovský, E.; Souto, E.B. Formulating fluticasone propionate in novel PEG-containing nanostructured lipid carriers (PEG-NLC). Colloids Surf. B Biointerfaces 2010, 75, 538-542. [CrossRef]

147. Araújo, J.; Nikolic, S.; Egea, M.A.; Souto, E.B.; Garcia, M.L. Nanostructured lipid carriers for triamcinolone acetonide delivery to the posterior segment of the eye. Colloids Surf. B Biointerfaces 2011, 88, 150-157. [CrossRef]

148. Gokce, E.H.; Korkmaz, E.; Dellera, E.; Sandri, G.; Bonferoni, M.C.; Ozer, O. Resveratrol-loaded solid lipid nanoparticles versus nanostructured lipid carriers: Evaluation of antioxidant potential for dermal applications. Int. J. Nanomed. 2012, 7, 1841-1850. [CrossRef]

149. Nayak, A.P.; Tiyaboonchai, W.; Patankar, S.; Madhusudhan, B.; Souto, E.B. Curcuminoids-loaded lipid nanoparticles: Novel approach towards malaria treatment. Colloids Surf. B Biointerfaces 2010, 81, 263-273. [CrossRef]

150. Taratula, O.; Kuzmov, A.; Shah, M.; Garbuzenko, O.B.; Minko, T. Nanostructured lipid carriers as multifunctional nanomedicine platform for pulmonary co-delivery of anticancer drugs and siRNA. J. Control Release 2013, 171, 349-357. [CrossRef]

151. Nam, S.-H.; Ji, X.Y.; Park, J.-S. Investigation of Tacrolimus Loaded Nanostructured Lipid Carriers for Topical Drug Delivery. Bull. Korean Chem. Soc. 2011, 32, 956-960. [CrossRef]

152. Agrawal, Y.; Petkar, K.C.; Sawant, K.K. Development, evaluation and clinical studies of Acitretin loaded nanostructured lipid carriers for topical treatment of psoriasis. Int. J. Pharm. 2010, 401, 93-102. [CrossRef]

153. Pathak, P.; Nagarsenker, M. Formulation and Evaluation of Lidocaine Lipid Nanosystems for Dermal Delivery. AAPS Pharm. Sci. Tech. 2009, 10, 985-992. [CrossRef]

154. Zhang, X.; Liu, J.; Qiao, H.; Liu, H.; Ni, J.; Zhang, W.; Shi, Y. Formulation optimization of dihydroartemisinin nanostructured lipid carrier using response surface methodology. Powder Technol. 2010, 197, 120-128. [CrossRef]

155. Sanad, R.A.; Abdelmalak, N.S.; Elbayoomy, T.S.; Badawi, A.A. Formulation of a Novel Oxybenzone-Loaded Nanostructured Lipid Carriers (NLCs). AAPS Pharm. Sci. Tech. 2010, 11, 1684-1694. [CrossRef]

156. Oberfeld, B.; Achanta, A.; Carpenter, K.; Chen, P.; Gilette, N.M.; Langat, P.; Said, J.T.; Schiff, A.E.; Zhour, A.S.; Barczak, A.K.; et al Snapshot: COVID-19. Cell 2020, 181, 954-954.e1. [CrossRef] [PubMed]

157. Zhou, P.; Yang, X.-L.; Wang, X.-G.; Hu, B.; Zhang, L.; Zhang, W.; Si, H.-R.; Zhu, Y.; Li, B.; Huang, C.-L.; et al. A pneumonia outbreak associated with a new coronavirus of probable bat origin. Nature 2020, 579, 270-273. [CrossRef] [PubMed]

158. Sohrabi, C.; Alsafi, Z.; O’Neill, N.; Khan, M.; Kerwan, A.; Al-Jabir, A.; Iosifidis, C.; Agha, R. World Health Organization declares global emergency: A review of the 2019 novel coronavirus (COVID-19). Int. J. Surg. 2020, 76, 71-76. [CrossRef]

159. Koirala, A.; Joo, Y.J.; Khatami, A.; Chiu, C.; Britton, P.N. Vaccines for COVID-19: The current state of play. Paediatr. Respir. Rev. 2020, 35, 43-49. [CrossRef]

160. Bloom, K.; van den Berg, F.; Arbuthnot, P. Self-amplifying RNA vaccines for infectious diseases. Gene Ther. 2021, 28, 117-129. [CrossRef] [PubMed]

161. Funk, C.D.; Laferrière, C.; Ardakani, A.A. Snapshot of the Global Race for Vaccines Targeting Sars-CoV-2 and the COVID-19 Pandemic. Front Pharmacol. 2020, 11, 937. [CrossRef] [PubMed]

162. Blakney, A.K.; Ip, S.; Geall, A.I. An Update on Self-Amplifying mRNA Vaccine Development. Vaccines 2021, 9, 97. [CrossRef]

163. Available online: https://www.ema.europa.eu/en/medicines/human/EPAR/comirnaty (accessed on 11 July 2021).

164. Aldosari, B.N.; Alfagih, I.M.; Almurshedi, A.S. Lipid Nanoparticles as Delivery Systems for RNA-Based Vaccines. Pharmaceutics 2021, 13, 206. [CrossRef]

165. Anderson, E.J.; Rouphael, N.G.; Widge, A.T.; Jackson, L.A.; Roberts, P.C.; Makhene, M.; Chappell, J.D.; Denison, M.R.; Stevens, L.J.; Pruijssers, J.; et al. Safety and Immunogenicity of Sars-CoV-2 Mrna-1273 Vaccine in Older Adults. N. Engl. J Med. 2020, 383, 2427-2438. [CrossRef]

166. Jackson, L.A.; Anderson, E.J.; Rouphael, N.G.; Roberts, P.C.; Makhene, M.; Coler, R.N.; McCullough, M.P.; Chappell, J.D.; Denison, M.R.; Stevens, L.J.; et al. An mRNA Vaccine against Sars-Cov-2—Preliminary Report. N. Engl. J. Med. 2020, 383, $1920-1931$. [CrossRef]

167. Kizzmekia, C.S.; Edwards, D.; Leist, S.R.; Abiona, O.M.; Barnum, S.; Gillespie, R.A.; Himansu, S.; Schäfer, A.; Ziwawo, C.T.; DiPiazza, A.T.; et al. Sars-Cov-2 Mrna Vaccine Development Enabled by Prototype Pathogen Preparedness. bioRxiv 2020, 583, 567-571.

168. Polack, F.P.; Thomas, S.J.; Kitchin, N.; Absalon, J.; Gurtman, A.; Lockhart, S.; Perez, J.L.; Pérez Marc, G.; Moreira, E.D.; Zerbini, C.; et al. Safety and efficacy of the BNT162b2 mRNA COVID-19 vaccine. N. Engl. J. Med. 2020, 383, 2603-2615. [CrossRef] 
169. Chung, Y.H.; Beiss, V.; Fiering, S.N.; Steinmetz, N.F. COVID-19 Vaccine Frontrunners and Their Nanotechnology Design. ACS Nano 2020, 14, 12522-12537. [CrossRef] [PubMed]

170. Available online: https:/ / ec.europa.eu/health/documents/community-register/html/h1528.htm (accessed on 26 December 2021).

171. Available online: https:/ / ec.europa.eu/health/documents/community-register/html/h1507.htm (accessed on 26 December 2021). 